\title{
Oplevelser i Sønderjylland 1. maj-9. juli 1920
}

En samtidig skildring

\section{Af Mogens Kai Norregaard}

\section{De første dage}

Der var stærk uro over os tolv civilklædte soldater, dengang vi, hin 30. april 1920 i Fåborg, med stigende utålmodighed ventede dampskibets afgang til Sønderborg. Vi var de allerførste, som blev sendt derned, inden overtagelsen endnu var officiel, for at sørge for, at alt var parat til troppernes ankomst.' Enhver af os mærkede for alvor, at nu stod vi foran enestående oplevelser. For dem iblandt os, der havde lejlighed til sammenligning, og som i tidligere tid, fra det sydlige Fyn, havde modtaget et uudsletteligt indtryk af, hvordan Als, en lille del af det store landskabs helhed, dog var et fremmed land, og ligesom en ond trussel, for dem var dette øjeblik som på selve tærsklen til eventyret.

Da landet endelig begyndte at forme sig, hvor vi spejdede, hvor vi grettede. Lysabild kirkespir, som danner centrum for den halvcirkel, hvori skibet runder Als, og som man i lang tid vedvarende har på samme plet lige ud for sig, mens skibet drejer, var det første kendemærke, der bed sig fast. Efter at have passeret den smalle tange Drejet, så vi den første mølle på den lille halvø Kegnæs. Vi stirrede så det sved i øjnene - var det Dybbøl? - Og så blev med eet al tvivl bortvejret, og det store, kuplede bjerg hævede sig forude, mens damperen ilede det i møde, og møllen tegnede sig endelig fast og utvetydigt ovenover gårdene og de fugtiggrønne marker længere nede ad banken, der satte sin gule lerfod i det grålige vand og på sin højderyg stolt bar landevejens træer i to store buer ned mod Sønderborg by.

Hurtig gled imens, til den anden side, Sønderskoven forbi, skydebanernes græsvold og lange betonmure, villa ved villa langs strandpromenaden; så kom det gamle slots fremskudte masse, vi rundede hjørnet og styrede i den skyede gråvejrsaften ind $\mathrm{i}$ havnen. - Dér mødte os et helt fremmedartet billede $i$ de tyske toldembedsmænd med de hæslige huer og C.I.S - politimændene, hvis mission først forekom os noget dunkel. ${ }^{2}$

Og efter en skærsild i tolden: Foden på Sønderjyllands jord. -

Om aftenen, i mørke, troede man sig hensat til en af de små, tyske byer. Der var kun lys ét sted på hovedgaden, og det bestrålede et skilt: »Ratsweinkeller«. Oppe i mørket skimtedes på en stor bygning ordet »Postamt “ i jernbogstaver, 


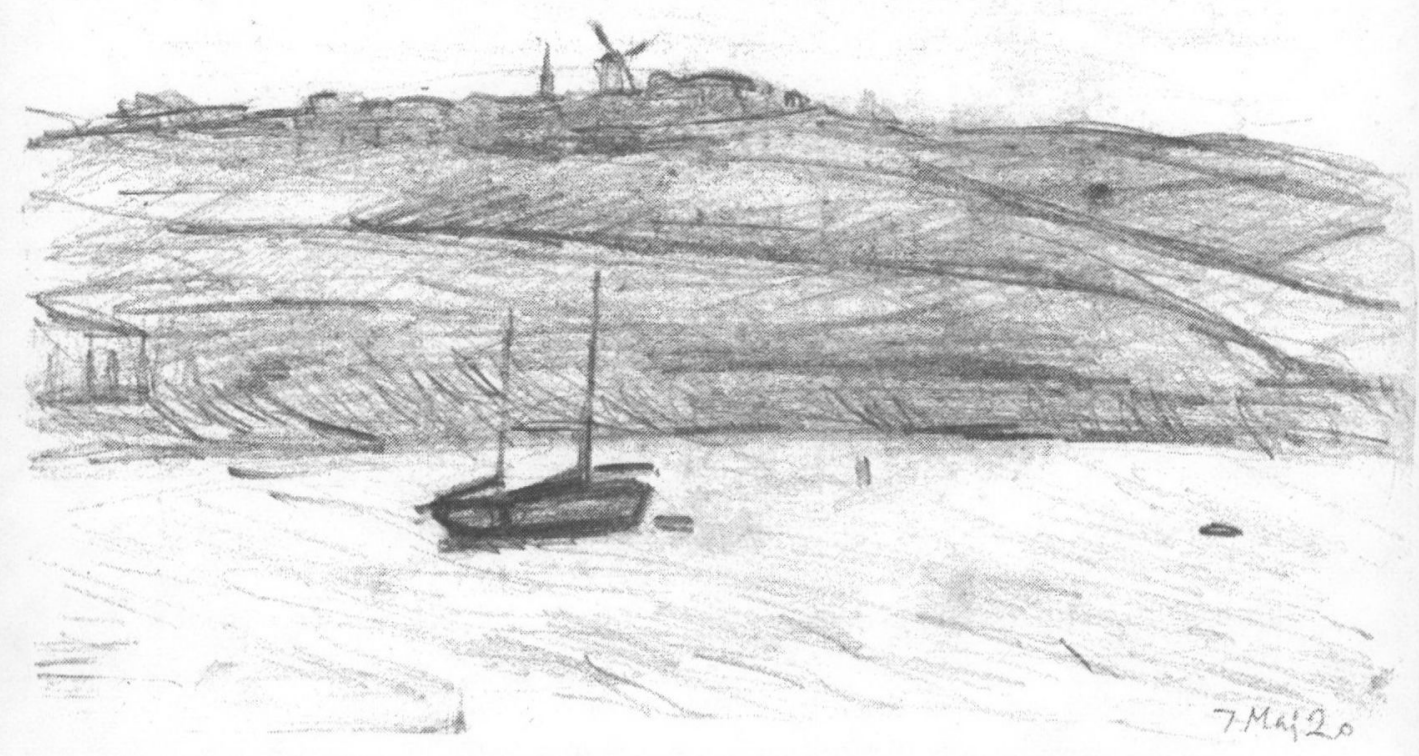

Udsigt over Alssund mod Dybbøl fra Marinekasernen i Sønderborg, den 7. maj 1920. På banken ses mollen og det preussiske sejrsmonument, rejst 1872 og sprangt i maj 1945. Skitse af forfatteren. (Privateje).

men det stod underlig skævt og forrykket fra midten. - Den næste morgen afslørede falmede pletter det kriminelle ord, der havde stået foran, og som man havde lagt sådan vægt på at skjule; man læste tydeligt endnu: »Kaiserliches -«.

Mægtige, som beregnet for skabninger af en hel anden art end dem, der havde bygget deres små huse $\mathrm{i}$ byen, forladte af alle, undtagen den snes alpejægere, ${ }^{3}$ der dannede vagtholdet, således lå marinekasernens to vældige bygninger. Øde vinduer i etage over etage, græs og ukrudt mellem brostenene, de store fortøjningspæle, der fulgte kystlinien op ad sundet, så langt øjet kunne nå, uden et eneste skib.

Jo mere man trængte frem $\mathrm{i}$ bygningerne, des mere blev man grebet af en tomhedsfølelse, der steg til uhygge. I den bygning, hvor franskmændene boede, lød der dog sang og fløjten op gennem trapperummet fra stueetagen; den anden lå hen i den mest knugende stilhed, kun nede i bunden af hele komplekset puslede, gamle og glemte, en portner og hans kone. På den anden 
side af den store, grusbelagte gårdsplads, højt tilvejrs på den grønne skråning, lå sygehuset, på hvis tagsten et stort, rødt kors på hvid bund stod malet til beskyttelse mod flyverangreb.

Inde i bygningerne var alt, hvad der kunne skrives på, oversået med navne, tal, datoer. Ind imellem læste man stolte skibsnavne: S.M.S. "König“, S.M.S. "Derfflinger" osv., nu vel forvarede i Scapa Flow. ${ }^{4}$ Oppe på loftet med dets utal af store rum og krinkelkroge finder jeg gamle, støvede papirer, kastede hulter til bulter. Jeg roder dem igennem og læser. Det er dagsbefalinger, ovelseslister, skydelister $\mathrm{i}$ hobetal. I den tomme bygning vidner de spottende om det daglige, koncentrerede arbejde her til stadighed har været udført gennem årene af skiftende hold mennesker. Den gamle tid er pludselig blevet kaldt til live, og man begynder at ane styrken af de kræfter, der skulle til for at få bugt med den, og forstår, at det er bølgeslaget fra en verdensomvæltning, som har standset livet på dette sted. - Her den sirligt forte skydeliste, for S.M.S. "Fuchs «: "Ort: Breit-Grund. Datum: 29. April 1914. Schiessaufgabe: Laufendes Gefecht mit geringer Abnahme bei bekanntem Kurs und Fahrt. Wetter: klar. Beleuchtung: günstig,“ etc. Eller også "Tagesbefehl Nr. 152. Sonderburg den 10. Juli 1914. Kirchliches: Sonntag den 12. d. Monats 9. Uhr vorm. Katolischer Gottesdienst im Hotel "Alssund ". Antreten auf dem Platz hinter dem Schulgebäude. Abmarsch $8.40 \mathrm{Uhr}$ vorm. Führung: der älteste Unterofficier, " etc. etc. ${ }^{5}$

Og ser man så ud ad vinduet, bliver man vidne til den nye tid, der holder sit indtog. Nedenfor, ved "Marsbrücke«, ligger damperen "Stærkodder" tungt lastet med materiel fra København, og mellem damperen og kasernen bevæger sig en broget skare i to rækker. Til den ene side de belæssede, der fra damperens hartad uudtømmelige last, med svære byrder, aser sig op ad skråningen til kasernebygningen, der sluger alt uden at blive mere fyldt for det. Til den anden side slentrer de lettede, så langsomt som muligt, ned for at hente mere. Det er tre nationaliteter, der her arbejder sammen. Livlige og flinke til at slæbe er alpejægerne, så er der de civilklædte, danske soldater og endelig lejede havnearbejdere. En artig blanding af højst forskellige typer og sprog, behersket af kasernetårnets ur, der højt til vejrs ligeligt afmåler hvile og arbejde for dem alle.

Udsigten fra marinekasernen begynder at blive tilvant. Det krappe, forårsblå sund og det røde slot, pontonbroen og hotel Alhambra. Langt borte viser Skelde næs mod nye egne. - Bænkene, uldtæpperne og hvad andre sager skibet indeholder, er tunge, og opgaven at fylde disse bygninger med materiel til soldaternes ankomst $d$. 5. maj synes ganske håbløs. - Uden "les chasseurs« var det heller ikke gået. Deres dragt er meget mørkeblå, ansigterne meget tobaksbrune, hvad der ser godt ud til de hvide cigaretter og den sorte baret. 
af hvor indgribende betydning dette er, for når visen er på tysk, bliver resten af legen det som regel også.

\section{Indtoget}

Næppe nogen i Sønderborg var rigtig klar over, hvornår jenserne egentlig skulle komme eller anede, at der virkelig allerede fandtes nogle af disse sagnagtige jenser iblandt dem, omend civilklædte. Jensernes ankomst var blevet udskudt så længe - akkurat som senere med genforeningen - så folk havde, trætte af forventningens spænding, bestemt ikke at tro noget, før de så det med deres egne øjne.

Jeg kan ikke nægte, at jeg havde fornemmelsen af at trykke på den knap, der satte hele maskineriet $\mathrm{i}$ bevægelse, dengang jeg på Sønderborgs telegrafstation indleverede telegrammet til chefen for »Olfert Fischer« i Assens med

Marsbrücke ved Alssund neden for Marinekasernen, der ses tilvenstre. Billedet giver et godt indtryk af distancen fra marinekasernen til anlobsbroen. Det er dog ikke "Starkodder “, man ser her, men "A.P. Bernstorffu, der bragte regering og rigsdag til genforeningsfesten pá Dybbol den 11. juli. I baggrunden Sonderborg. (Museet på Sonderborg slot). 


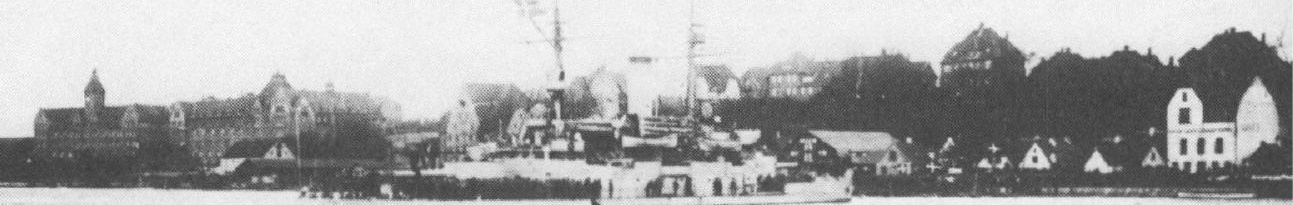

"Olfert Fischer « med mandskabet opstilles pả agterskibet er ved at lagge til i Sonderborg den 5. maj 1920. Til venstre marinekasernen, til højre den ventende menneskemangde med Dannebrog pd kajen neden for Havbogade. (Museet på Senderborg slot).

anvisning på, hvor han skulle lægge til i havnen; det var det sidste, der skulle til, før de danske soldater igen kunne tage landet $\mathrm{i}$ besiddelse. ${ }^{8}$

Men hvilken forskel på byen, som den var umiddelbart før de to historiske fester: jensernes ankomst og genforeningsfesten. Det var som to helt modsatte byer, den ene grå og fattig og stille af bare mangel, og den anden blussende i ivrig, højrøstet glæde, stormende imod alt det nye.

Højst forskelligt modtog de folk i byen, der havde staldplads, meddelelsen om, at de skulle have militærheste indkvarteret. Kun med kniberi fik man anbragt de to heste, som hver af dem gennemsnitlig skulle have, hos de tysksindede, hvis kontorer bar et lige så afgjort særpræg som de tyske, unge piger på gaden, der i en mængde bagateller røbede deres nationalitet; et blik var $\mathrm{i}$ begge tilfælde straks orienterende.

I modsætning til den træge modtagelse hos de tyske firmaer og handelshuse var det derfor forfriskende at blive budt et åbent velkommen oppe $\mathrm{i}$ gæstgiveriet »Koldinghus«, hvor værten satte punktum for min dags arbejde med at tilbyde hos sig alene at tage alle de resterende otte heste.

Et andet sted, også $\mathrm{i}$ et gæstgiveri, stod en ung, bleg pige i sort og hældte en snaps op i en kop kaffe til en gæst i skænkestuen. Da jeg forhørte om staldplads, sagde hun, mens tårerne begyndte at løbe, at hendes fader var død om natten, "lige før den dag, de danske soldater kommer, det, han havde glædet sig til hele sit liv«. Nu kom også moderen til, der var ikke tale om andet, end at de ville have deres indkvartering som de andre. Gæstgiveriets navn var "Danmark «" 
Ovre på statsbanegården, hvortil militærhestene skulle komme, dryssede kalken ned fra væggene. Alt skramlede i det rullende materiel, og alt, hvad der kunne ruste, var ræverødt. Trist og hæslig var stationsbygningen $i$ forvejen, så det var ikke opbyggeligt. De, der hørte til derovre, så også endnu mere blege og forknytte ud end de øvrige statsfunktionærer, krigsprægede allesammen. En imødekommende, gammel stationsforstander, der nu nyder sit otium i Holsten et sted, ordnede alt vedrørende transportens ankomst.

Kun et kvarterstid før "Olfert Fischer « med tropperne om bord ventedes, ankom toget, der medførte, foruden træn, rekylheste og kuske, oberstens hest og alle stabshestene. ${ }^{10}$ Det var derfor et såre spændende og pinligt øjeblik, da "Olfert Fischer«s himmelhøje, grå master, til den fastsatte tid, bevægede sig ind gennem sundet, og man helt herover til statsbanegården folte spændingen i de ventende masser på den anden side og hørte hurraråbene begynde at bølge ud over vandet blandet med toner af fædrelandssange. - Thi det havde været mindre festligt, om oberst, oberstløjtnant, stab og hvad dertil hører, til fods skulle have bevæget sig igennem Sønderborgs gader under indtoget. Men der manglede kun såre lidt $i$, at de var kommet til at gøre det, hvad ingen skulle have anet, da de sorgløst satte sig op på deres heste.

Transporten var ikke blot forsinket, den havde tillige stået hele natten

"Olfert Fischer" har netop lagt til. Honoratiores og tilskuere tranges på landgangsbroen, og på kajen er de franske alpejagere og byens spejderkorps opmarcheret. (Museet pả Senderborg slot).

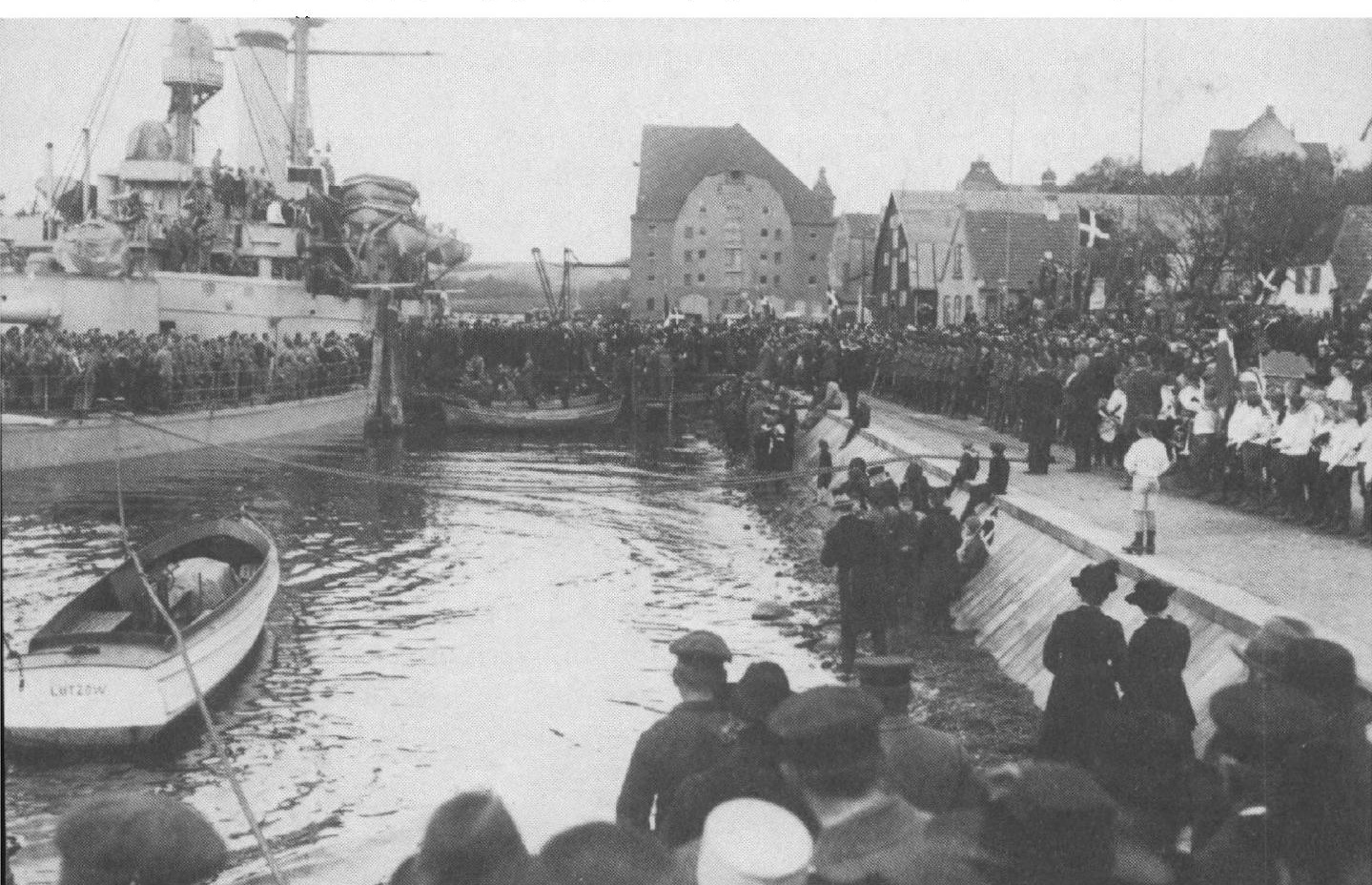




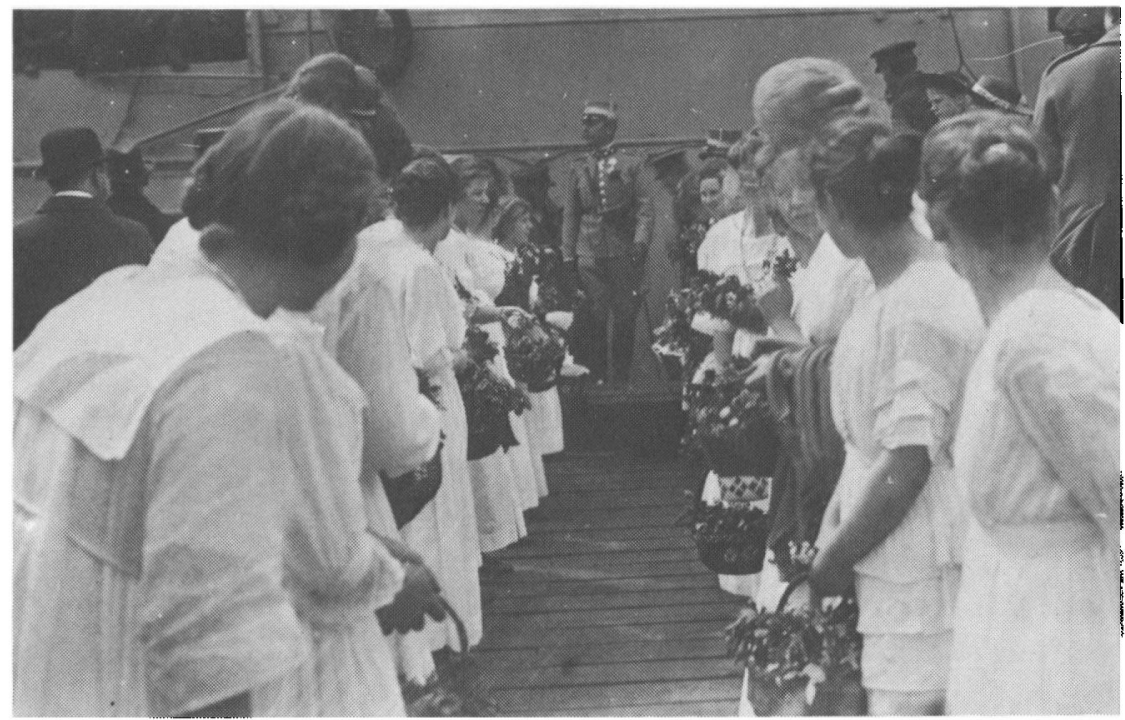

Oberst C.C.F. Moltke (1867-1955), chefen for 8. regiment og Senderjydsk Kommando ved genforeningen, går $i$ land fra "Olfert Fischer" og modtages af hvidkladte, unge piger med blomsterbuketter. (Museet pả Senderborg slot).

over $\mathrm{i}$ vognene på stationen Flensburger-Weiche, hvortil den var nået efter alskens genvordigheder og trakasserier, som de tyske jernbanefolk havde beredt den, og heste og mandskab var lige udasede og upræsentable. Det var derfor kun med opbydelsen af al energi, at det lykkedes at få opsadlet de vigtigste heste med det samme og få dem ført over pontonbroen og klaret gennem den tætpakkede menneskestimmel. - Gudskelov for taler og sange; det var takket være dem, at alt var parat, da obersten kom.

På havnekajen kneb det svært med at få plads for de mange mennesker og med at føre bataillonen hen på torvet, hvor den egentlige modtagelsestale blev holdt. Da ceremonien var til ende, satte toget sig under stor bevægelse i gang. Fra pontonbroen havde man det bedste overblik over det.

Forrest gik den dansk-franske kaptajn Dederding med kasernekommandanten i Sønderborg, kaptajn Krenchel. ${ }^{11}$ Derefter fulgte alpejægerne. Musikken sætter i, og det giver et sæt i publikum, da hornblæserne med ét i strakt arm jager trompeterne i vejret og lader det blanke metal skyde lyn $i$ luften. Efter musikken ses i hastig vuggende takt de lange, sorte, sylespidse bajonetter og under dem de mange kendte ansigter, anspændte og ivrige. Det var "la chamade «, ${ }^{12}$ udfordrende, krigerisk, inciterende. - Lige efter 


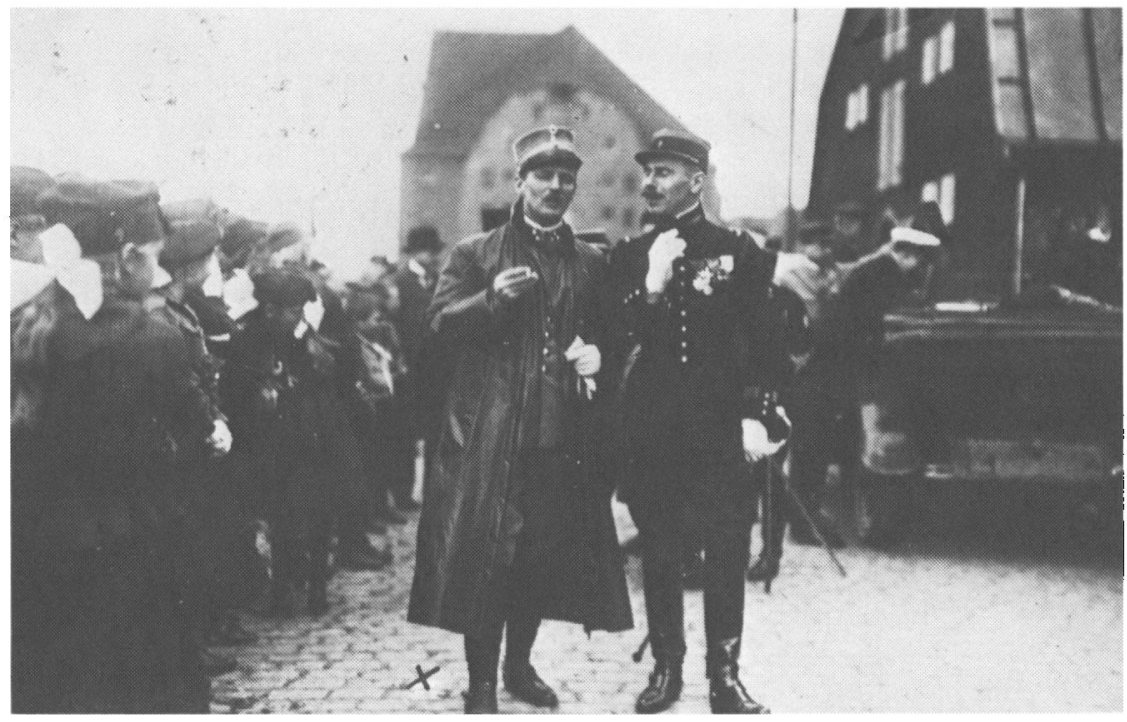

Kasernekommandanten $i$ Senderborg og forfatterens chef under alle Flensborg-turene og under forhandlingerne med de engelske myndigheder og C.I.S., kaptajn Harald Krenchel i samtale med den dansk-franske kaptajn Dederding (th.) pả kajen i Senderborg den 5. maj 1920. (Privateje).

fanfarerne fra "les chasseurs « lyder "Den gang jeg drog af sted « for fuld kraft af pauker og trommer. Den sorte skare med de høje hatte og hvide skæg var veteranerne. Så kom - til hest! - oberst, oberstløjtnant, stab, og tilsidst jensernes grå masser, blomstersmykkede, forventningsfulde. Hovedgaden var helt rød af Dannebrog, men de store, offentlige bygninger lå udeltagende hen uden flag, overtagelsen var jo ikke officiel endnu. Fra møllens vingespidser viftede Dannebrog, man kunne følge flagene gennem sidegaderne, og hvor man så det vaje, vakte det en stadig stærkere følelse af rigdom, tryghed og lykke. -

Marinekasernen var så vidt parat, som den efter omstændighederne kunne være. Det vil sige, at nattelejet var på tangmadrasser på det bare gulv. Gasblussene var ødelagte, så vi havde enten lys i en flaske eller i en staldlygte eller slet ingen ting. Desuden var alle knager blevet fjernede inden evakueringen, så at alt tøjet og alle udrustningsgenstandene lå $\mathrm{i}$ indfiltrede bunker rundt om på gulvet og så fantastiske ud i det flakkende halvlys, når man "gik i seng«.

Men skønt var det næste morgen at se Dybbøl banke med sin mølle højt til vejrs på den anden side af det blå sund, der snoede sig dybt nede under os. 


\section{Festerne}

\section{På Dybbel}

Den allerførste dag, da vi drog ud med fuld musik og med marinerne fra "Olfert Fischer« bag efter os, for at bekranse krigergravene ovre på Dybbøl, kom vi, oppe ved kirkealléen, forbi skolen, hvor alle skolepigerne med deres lyse, runde hoveder, myldrende og puffende, fyldte vinduerne. Pludselig gav de sig til at synge, jublende, skingrende, så vi kom ud af takt: »Den gang jeg drog af sted". Med dette jubelskrig sprængte de langt bort for evigt alle trange og trykkende minder om "Ich bin ein Preusse, ein Preusse will ich sein «. Med dette skrig blev $v i$ indviede til Sønderjylland; de der før havde spillet overlegne, de kom med, akkurat som den gang tropperne holdt deres indtog $\mathrm{i}$ København efter Treårskrigen. Til at begynde med, da de samledes ude på Vesterbro, var de kry nok og, efter soldaters vis, en smule overbærende, for enhver pris ikke betagne eller imponerede; men da de så marcherede ind mod byen, da havde også et skrig, det jubelskrig, der lød imod dem fra Københavns menneskefyldte volde, givet dem indvielsen.

Først da vi var oppe på toppen af Dybbøl og efter at have nedlagt kranse på gravene, nu med hele landet foran os marcherede ned til det, ind $i$ hjertet af det, fik vi helt fornemmelsen af, hvad den nærmeste fremtid ville bringe. - Det var regnfuldt og pløret, og skyerne hang lavt ud over bakkerne, mens alle blade og strå glinsede af væde. Da musikken begyndte at drage ned ad bakken efterfulgt af bataillonen, sprang pludselig de rødhvide flag ud rundt omkring over stråtage og huse nede i Dybbøl by; allevegne var der flag i bevægelse op til flagknappen, vor vej fremad betegnedes med flag, der gik til vejrs, og hvor vi kom, inden de kunne nå at få det hejst, stod de med det i dørene og viftede, mens børn løb efter os med små flag i hænderne. Og gårdene, som kort forinden havde ligget hen som uddøde, var med ét slag forandrede. - Det var vor første tur, og for enhver af os blev det afgørende. Det var hjerte, der fløj til hjerte, og når vi var rigtig tæt på, så vi ofte, at de græd. ${ }^{13}$

Det var i sandhed dage, hvor man spurgte sig selv, om det nu også kunne være virkelighed altsammen. Det dagligdags havde slet ingen gyldighed mere, og jenserne var ganske løftet ud af al sædvanlig form og utilbøjelige til at acceptere de mere prosaiske tider, da de igen meldte sig.

\section{Augustenborg}

Med stor forventning imødeså jeg Augustenborgturen. Jeg længtes efter at se den gamle conspiratorrede midt $i$ det troskyldige Als.

Fra et højdepunkt på Kjær halvø blev vi orienterede $\mathrm{i}$ hele det vide, pragtfulde landskab, der lå udbredt foran os, før vi begav os ind i det. 


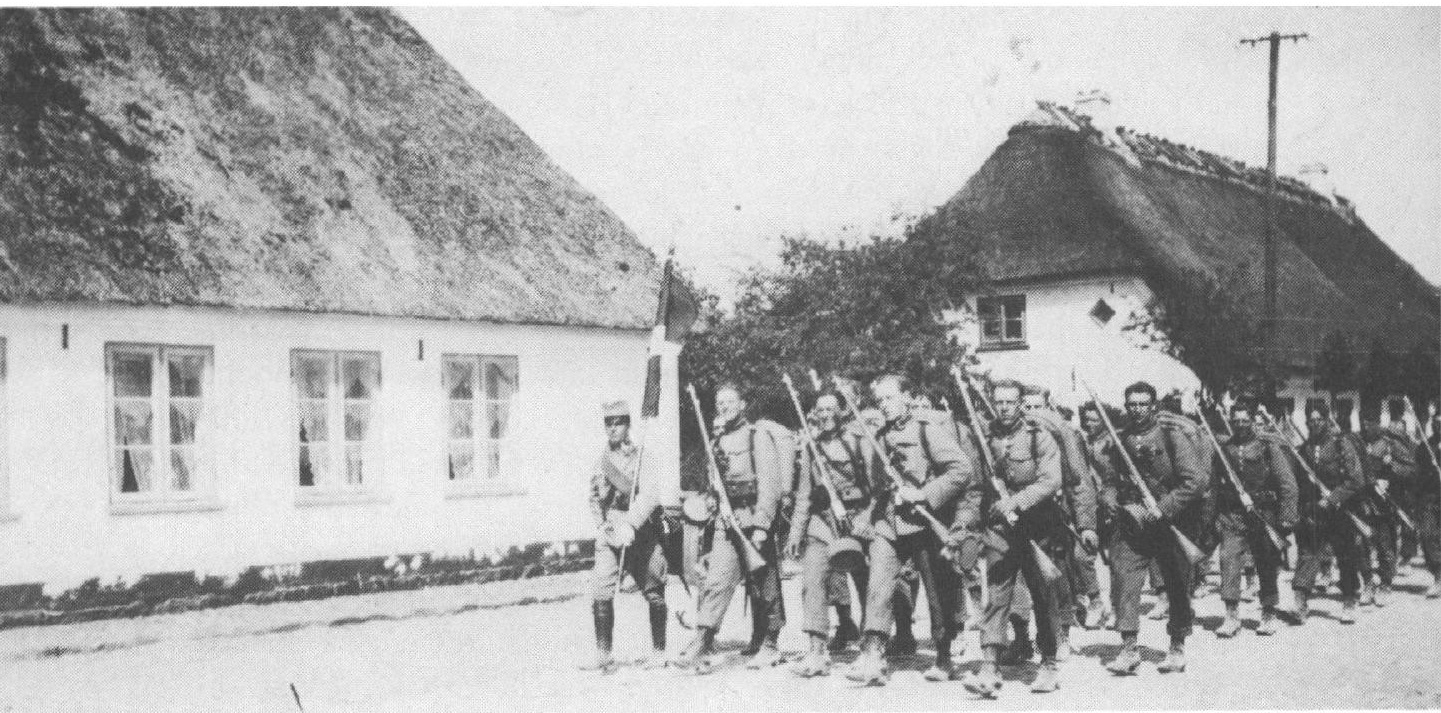

Fjerde kompagni marcherer gennem landsbyen Kjar. (Privateje).

Bindingsværksgårdene med de tre længer, der åbner sig ud mod vejen, de mange, klippede buxbomhække og lindetræer, det sirligt strøede grus i havegangene, de brede, blanke ruder i alle vinduerne, de hvide, stivede gardiner indenfor, hvis indvævede blomster snart var lige så håndgribelige som de kæmpemæssige, blomstrende pelargonier, der stod i karmen i strålende fajancepotter; jo, Als var ikke længe om at vise sig i sin fulde særprægethed, og landsby efter landsby talte stadig tydeligere det samme sprog til os.

I skoven, før man kommer over fjorden, holdt vi hvil i glad forventning, fiksede op på påklædningen, det vi kunne, og spiste noget af den medbragte mad, for ikke at komme til at æde alt for ubeskedent. På den anden bred af fjorden stod ved opgangen til byen unge piger med en stor, frisk buket. Den officer, som modtog den, gjorde de unge piger opmærksomme på, at oberstløjtnanten først kom bagefter, og at han kun var kaptajn. ${ }^{14}$ Nydeligt svarede så den unge pige, der havde overrakt ham buketten, at de blomster var til den første, danske soldat, der betrådte Augustenborgs grund, så var det lige meget, hvad rang han var af.

Som til alle de store slotsanlæg bliver man også her grundigt forberedt og højtideligt stemt af en lang allé. Den er høj og mørk og lukkes for enden af porttårnet. Helt oppe mødte øjnene et "velkommen« spændt tværs over 
vejen, og under det hvidklædte småpiger, der sang. Slotspladsen blev snart et levende mylder af gråklædte jenser, lysklædte piger og mørke civilister, der her spillede en mere tilbagetrukken rolle. Henne i hjørnerne var trængslen stor om udskænkningsstederne, herligt skummende øl og grisk bællende soldater og topfyldte smørrebrødsfade, der ikke fik tid til at smelte i solvarmen. Der var stille glæde hos augustenborgerne ved at se på jenserne, mens de spiste, og den steg, da de så dem hvirvle sig til musikken med de hvidklædte på slotspladsens grus. - Nogle fandt op i porttårnet ad en ret brøstfældig trappe, der endte på en forbavsende knudret måde, indtil man tilsidst strakte hovedet ud over rækværket og så ud og ned på vrimlen og støvet på den store, firkantede slotsplads. Der var meget lidt plads deroppe til andre end den irrede, grønne klokke, der hang brændende hed af solvarme i midten med allehånde, snørklede forsiringer, tal og inskriptioner. Det var et festligt skue heroppefra. Uden om slottets skinnende hvide fløje, der omsluttede festtumlen, bredte sig milevidt et strålende landskab med bakker ud til blå fjorde, grupper af træer og grupper af huse omkring kirkespir. Al Danmarks ynde lå samlet for ens blik. Og det blev altsammen forklaret for os, og med ivrige bevægelser blev der peget ud over egnen hvad det var, der lå der, og det, der lå der. Og de tunge lodder til uret, som det jo nok kunne knibe for en ung pige at trække op en hel vinter igennem, mens hendes fader lå syg. Selve slottet, nu seminarium, ${ }^{15}$ åbnede også sine lyse, kølige gange for de danske soldater. Fire, sortklædte vejvisersker bevægede sig geskæftigt og husvant $i$ gangene, utrættelige $i$ at vise os og fortælle os om alt, hvad vi så og om dobbelt så meget til; dør efter dør åbnede de til klasseværelserne eller lærerindeboligerne, og i stueetagen viste de os den smukke aula, den eneste levning indvendig fra slottets glansperiode. På trappegangen et stort billede af dronning Louise af Preussen, »den preussiske madonna «, og et af den tyske eks-kejserinde, der jo stammede fra Augustenborg, og som de nævnede med sympati. ${ }^{16}$ Men deres første og sidste tanke var at få Dannebrog hejst på slottet. Før kunne der ikke leves videre i den bygning. En betegnende instruks til de unge lærerinder, som før gik på seminariet, og som næsten alle var tyske, lød således, at hvis man på legepladsen overraskede børn $\mathrm{i}$ at tale dansk, skulle det meldes til bestyrerinden, og børnene straffes.

Nede i parken standser man overrasket ved "palæet « og forstår navnet „Eden«, som det litterære hof gav Augustenborg i gamle dage. Den lille, hvide, nyklassiske bygning ligger helt skjult, man ser ikke engang slottet derfra, og ikke en lyd fra festen nåede derhen. Fjordens vand blinker frem for enden af alléen, og høje, røde blomster vokser inde under skyggen af mægtige bøge. Man skelner en høj, det er "pulverkammeret«, en anden, det er hertugens hests grav; så er der H.C. Andersens træ med mindepladen på tysk, 


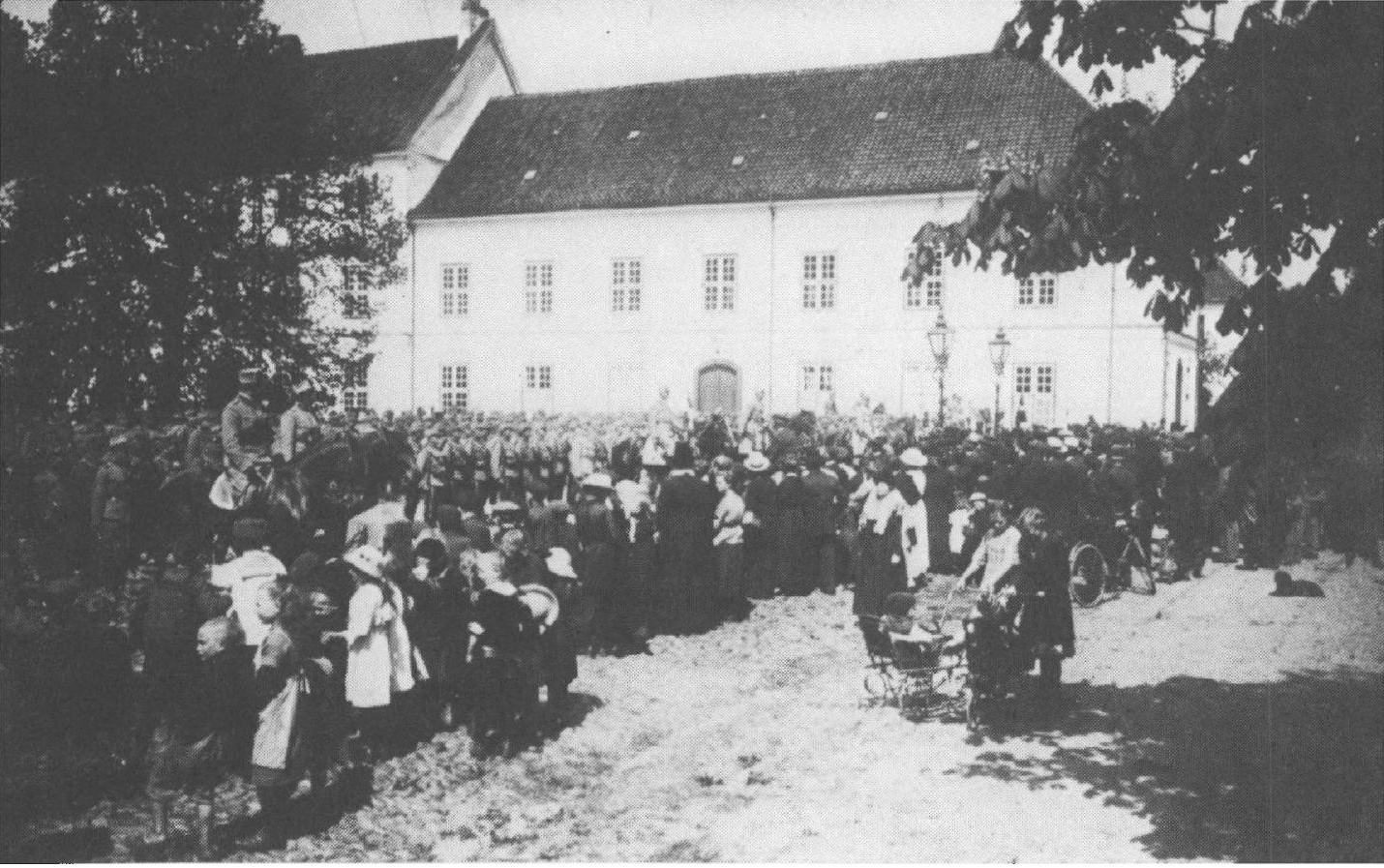

De danske soldater på slotspladsen foran Augustenborg slot. (Museet på Sønderborg slot).

de tre ege, "die Schwureichen «, ${ }^{17}$ hvorunder, efter sagnet, Griffenfeldts fald blev besluttet, og mangt og meget andet, og parken er tæt, og jenserne havde forvildet sig dybt ind i den, da der blæstes til samling. På den indre, brolagte slotsplads holdtes der nu parade, fotografiapparater rettedes ind på os allevegne fra, og ned gik det gennem hovedgaden under fuld musik. De gamle huse lå som det nydeligste supplement til slottet, med store stentrapper bygget ud over toppede, græsomgroede brosten, udskårne rokokodøre, dørhammere, små ruder, slyngroser, teglstenstage. Gennem hulveje over landsbyen Bro, uden om fjorden, gik det så hjem.

\section{Festen $i$ Katrinelund}

Festen i Katrinelund den 16. maj var den officielle fest, hvor Sønderborg bød tropperne velkommen. Allerede om morgenen vajede flagene overalt, og ikke mindst flagsmykket var Adalbertgaden, ${ }^{18}$ der vender ud mod kasernen, og som med sine fantastisk hæslige, tyske facader så helt menneskelig ud med Dannebrog. Det var søndag, og vi var ualmindelig rene og lettede for alt, hvad der hed oppakning, da vi marcherede ud med spejderne i spidsen. Gennem hele byen var det en uafbrudt nikken op til vinduerne, hvor folk lå ud og vinkede. På vor march havde flere og flere sluttet sig til os, så at en 
mægtig sværm gik og løb og cyklede $i$ vejkanten, da vi kom uden for byen, og fra hele toget lød en konfus brusen af sang og latter. Fra vejen lettede støvet $i$ tykke, blålige skyer og gled ind imellem og ind under rosenrødt blomstrende frugttræer. - Med højtløftede bøgegrene stod unge piger i friske, hvide kjoler og dannede ved indgangen en portal, hvorunder hele toget gik ind til festpladsen. Her var det som en fanfare af smældende sollys på alle de hvide duge henad de lange borde med skinnende kopper og kander og yderst ude i diskanten det skære, nyudsprungne bøgeløv isprængt Dannebrog. Og nu skete Sønderborgs formæling med jenserne. Vi var overvældede. Var det for os, at alt det blev gjort? Hvordan havde vi dog fortjent det? Og de ord, der var skrevet i sangen, de var som til en søn, der pludselig er kommet tilbage: "Velkommen her igen, vor egen, kære Jens". Véd nogen af dem, der har siddet hjemme i kongeriget mon, hvad festen i Katrinelund var? Dér talte Nis Nissen til os om krigen. ${ }^{19} \mathrm{Og}$ mange begyndte at forstå ting, som før kun var anelser. $\mathrm{Og}$ ind imellem talerne kom sangkoret, bl.a. med genforeningssangen. ${ }^{20} \mathrm{Og}$ som løftet af den store stemning fik en af jenserne mælet ${ }^{21}$ til at sige det, som de alle følte, det som var sandhed for hver eneste én af dem, der sad bænkede dér og kæmpede med mange følelser, som vel for de fleste var nye og overvældende, og som de ikke før havde haft brug for at søge ord til. Det var festens højtideligste øjeblik.

Henimod klokken otte, netop som solen var gået ned, drog et livligt tog henover markerne fra Katrinelund, hvor middagens overdådighed og sange havde bragt stemningen på et højdepunkt. Henad de bugtede markveje bevægede hele bataillonen sig i marchkolonne op imod chausséen, hvert kompagni med sin kaptajn i spidsen, men under hans kommando var der den aften, foruden jenserne, de sønderjyske piger, som jenserne havde taget under armen. Al modstand var på forhånd opgivet, og med triumfråb inkorporeredes de nye soldater i rækkerne; bataillonen slugte dem alle, som den kom frem ad vejen under råb og sang, så det klang langt ud, og folk strømmede ud af gårdene og ud $\mathrm{i}$ haverne og stod bag hækkene og lo og vinkede igen, mens de grå soldater med de hvidklædte piger imellem sig og med de pragtfulde bøgegrene, som svingede og vinkede fra alle de larmende rækker, drog forbi. Tre store sale var den aften fyldte til trængsel, og det blev en hård tur for damerne, som var i fåtal, og som uden en pause trådte dansen til helt ud på natten. Den aften blev mange bånd knyttede, tværs over alt hvad der havde skilt. 


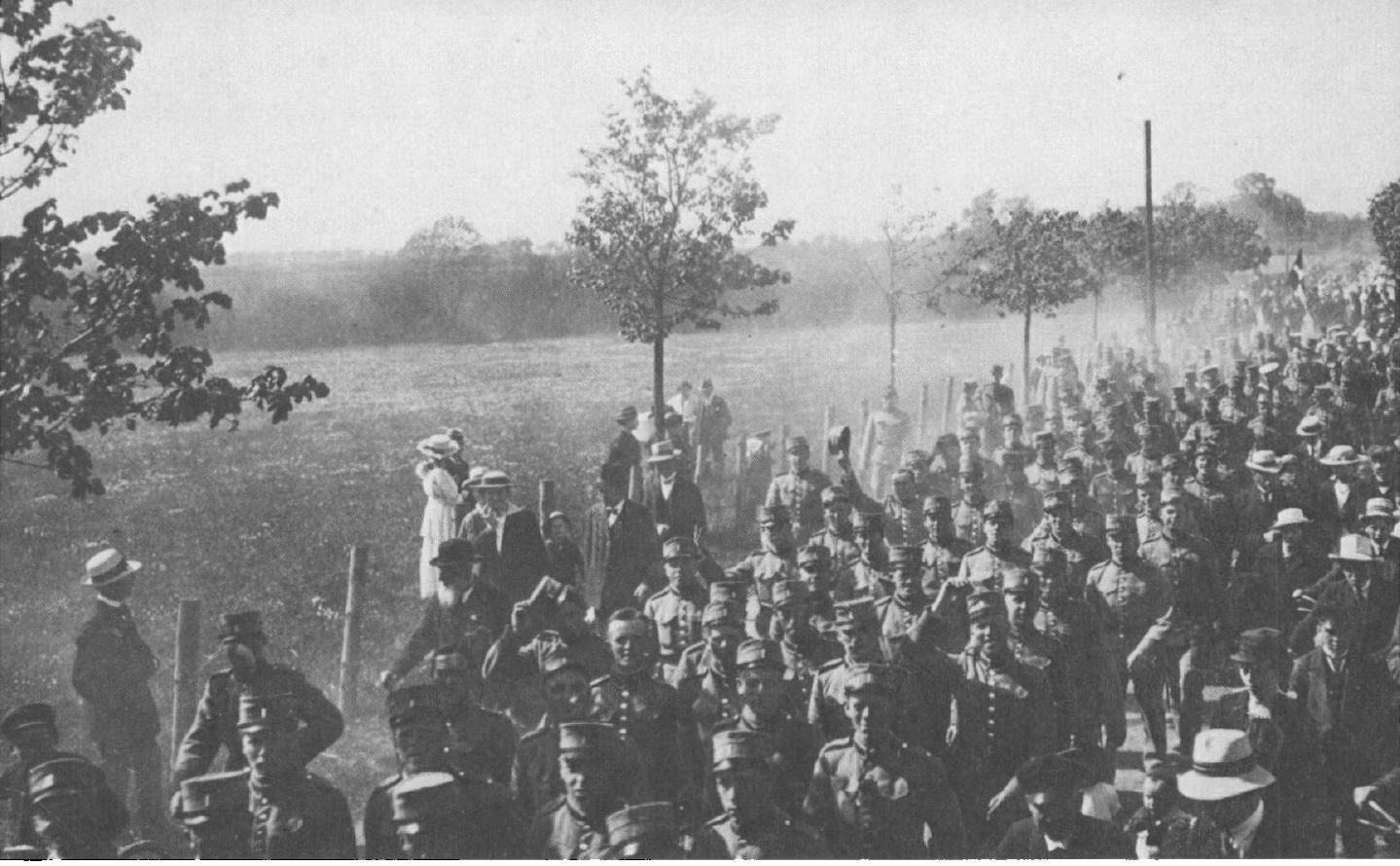

De danske soldaters indmarch til festen i Kathrinelund den 16. maj. (Privateje).

\section{Festen i Ragebel}

Som typisk for de dages festligheder i småbyerne i Sønderborgs nærhed, vil jeg omtale festen i Ragebøl. ${ }^{22}$ Foran skolen stod skolelæreren og arbejdede i haven, da vi kom forbi. Han stødte arrigt i jorden med spaden, da han så os; det var Ragebøls eneste tysker foruden stationsforstanderen. I gamle huse kom gamle ægtefolk frem i dørene, og hun kiggede frem bag hans skulder og nikkede, mens han tog hatten dybt af for hver befalingsmand, der marcherede forbi. De smilede med de indfaldne munde, men havde store tårer $\mathrm{i}$ øjnene, og vi gik med den underligste fornemmelse $\mathrm{i}$ brystet og halsen. Efterhånden som vi blev mere vant til det, fik vi indstuderet et hurra, som begyndte med et trefoldigt hurra i første deling, og så blev grebet af anden og sådan trefoldigt rullede fra deling til deling ned gennem kompagniet. Der blev ikke sparet på det. Heller ikke på sange, og først og fremmest „Den gang jeg drog af sted“ og så "Madelon «. ${ }^{23}$ - En lille pige med rødt skærf om sin hvide kjole stod parat hos sin moder med buketten af de røde og hvide blomster og gik frem mod premierløjtnanten, da han kom på sin store hest. Han måtte læne sig helt ned så langt, han kunne, for at nå den lille piges hånd med blomsterne. En mand stod frem og holdt en af disse hjertelige velkomsttaler, vi så ofte fik at høre, og som hver gang fik mig til at undre mig 
over, at det fandt vi hernede efter over et halvt århundredes fremmedherredømme. Mens vi endnu stod opstillede under talen, kom små piger hen til os med blomster, lilliekonvaller, syrener, stedmoders, som de nejende rakte os. Foran Ragebøls forsamlingshus stod en skare af folk fra egnen, og iblandt dem gamle veteraner. Dem tog officererne sig af og viede dem hele deres opmærksomhed, og lykken strålede i de gamles ansigter, da de sad bænkede ved kaffebordene mellem alle soldaterne, og man hørte i et væk deres høje, spæde gammelmandsstemmer. -

Vi så til hinanden, da vi var anbragt ved bordene og havde lagt de blomsterprydede huer fra os i vinduerne. Det var utroligt, så der var blevet dækket op for os, og hvilket arbejde måtte det ikke have været at fả al den mad smurt og alle de kager bagt. Det var, som om de ville vise os, på en for soldater letforståelig måde, at det var grænseløst, hvor meget de ville unde os. Fadene rørte ved hinanden over hele bordets længde, og der var ligesom lidt betænkelighed ved at bryde hul og ødelægge det festlige syn. - Vi nåede da også langtfra at få spist op, og det skønt hver især gjorde sit bedste; der kom stadig nye, topfyldte fade af stadig samme overdådige lækkerhed, og vi åd, til vi var revnefærdige og ikke kunne spise mere den dag. - Stille gik en ældre mand op på tribunen. Han havde sort skæg og en skarptskåret profil og stod med nedslagne øjne, mens han fortalte. Det var om den gang, han sidst havde set de danske soldater. Her på samme sted. På vejen derudenfor, som vi var kommet ad. Ordene husker jeg ikke. De faldt langsomt og søgende, alt som mindet dukkede frem, og det var ikke til at mærke på ham, at han stod $i$ en stor forsamling. Men det billede, ordene fremkaldte, står lige så levende for mig, som havde jeg oplevet det selv: soldaterne, der kom fra Dannevirke, sneen, hvor bålene brændte og maden kogtes, og en lille dreng, der lykkelig, uden at ane, hvad det var, han så, stormede rundt fra den ene gruppe til den anden. - Det var dog blevet et indtryk for livet, og stedet, hvor det var sket, kunne han endnu forklare os, hvor var.

Salen blev ryddet og fejet, og der var snart fuldt på gulvet af dansende.

\section{Dybbol skanser}

Blandt vore mere rolige dage husker jeg især dengang vi havde foredrag af premierløjtnanten oppe på Dybbøl. På den grønne vold af en af de senere anlagte skanser, omtrent ved den gamle skanse 2, sad hele kompagniet. Kalvene var blevet lige så ængstelige som nysgerrige ved vor ankomst $i$ deres indelukke og sprang undersøgende til og fra. Når man gik op ad det stejle bjerg nede fra pontonbroen, var det umuligt at lade være med at tænke på, at det var jenser ligesom os, som i 1864 måtte op i skanserne og lade sig skyde ihjel, og som godt vidste, hvad de klavrede op til. Jeg tror, de gjorde det, 
ligesom vi nu ville gøre det - uden tøven og uden begejstring. - Lige overfor det forsamlede kompagni lå, på den anden side af Vemmingbund, Broagerland med Dynt mølle, ensomt arbejdende i det dystre landskab, og med Broager kirkes to dristige lybakkerspir ${ }^{24}$ over alle de hvide gavle i regelmæssig række i byen nedenunder. Så typisk et jysk landskab, og i stærkeste modsætning til det blide, bølgende Als. Dette vekselspil imellem de to naturer, hvoraf Danmark består, det mandlige og det kvindelige, fastlandet og ølandet, der mødes ved Alssundet, gør landskabet ualmindelig udtryksfuldt, ualmindelig dramatisk. Den kæmpemæssige kuppel, som Dybbølbjerg danner, og som behersker hele landskabet på begge sider af sundet, ville sikkert være berømt også uden sine historiske minder. - På en pløjemark så vi stenen over løjtnant Anker. Der var pløjet helt hen til den, og der hang kun en gammel, vissen krans. - Ellers betegnes gravene på lang afstand af en tårepil, og går man hen til dem, ser man næsten altid friske kranse eller blomster ved stenen. Foredraget gjorde på mig et stærkt indtryk ved den håndgribelige virkelighed, stedet gav fortællingen. Gammelmark på Broager fik nu sin uhyggelige betydning. ${ }^{25}$

Der var en bræmme af blomstrende vilde roser og hyld og tjørn langs hele brinken, og nede $\mathrm{i}$ alle kløfterne var der et væld af blomster, hvorunder kilderne randt ned; længere nede kom de frem gennem det smaragdgrønne græs og tilsidst løb de gennem leret ud i Østersøen, der strakte sig fra klintens fod og så langt ud, øjet kunne nå. Bølgerne gled klare som glas henover skiftende bund af grønligt sand og purpurfarvet tang, og små mennesker i hvide både langt ude på havet havde travlt med at hale ind eller sled i det for at komme over til Kegnæs.

\section{Om krigen}

Det vil altid være vanskeligt for dem, der ikke har set det, at forestille sig, hvor hårdt et præg Sønderborg, ja hele Sønderjylland havde, førend den friske strøm kom skyllende nordfra. Hvor det var afsondret fra al livets glæde og farve. Hvordan man alle vegne så ansigter, hvor den gustne hud lå stramt spændt over kindben og tindinger, med hårde træk om munden og et underligt, langtsøgende blik. Hvor mærkeligt blide og rødmossede de danske soldaters ansigter virkede hertil med deres mange muligheder og skiftende udtryk. - De mange krigstrætte ansigter havde kun et og det samme, selv når de smilte.

Menneskenes dragter kappedes $\mathrm{i}$ forsømthed og tristhed med husenes facader. - Man så overalt den feltgrå, i original eller dårligt camoufleret, og al 
farve var forlængst regnet af mure og træværk. De sorte og hvide spiraler på de preussiske flagstænger var vasket $i$ én regngrå stribe. - Svarende til alle disse ydre træk, kom så de indre. -

For enden af enhver samtale lå det hav, hvori alting mundede ud: Krigen! Undertiden kortere bemærkninger, som kastede uventede strejflys og viste én kombinationer, som man ikke før havde tænkt over, eller også, sjældnere, fordi de færreste er $i$ stand dertil, en fuldstændig fremmaning af det altsammen.

Det, der gjorde mest indtryk, var naturligvis, hvad de jævnaldrende eller endog lidt yngre havde at fortælle. Her hørte man den historie, der ville være blevet ens egen, om man var født $i$ et af de store lande. Soldaterbogen blev halet frem med den største sindsro af ejermanden og betragtet med undrende ærefrygt af den, der intet havde ydet. Den var herlig positiv og indeholdt, kort og præcist, hvor og hvornår, alt hvad der kunne sættes i navne og tal. Det var ikke lidt en sådan godt 20-årig ung mand kunne have været med til. - Indtil en halv snes navne, hvoraf de fleste er betegnelser på store slag i Verdenskrigen: fra Somme og Chemin-des-Dames til russiske og polske slagmarker, stod opklæbet i bogen under hinanden, dertil en omhyggelig dateret fortegnelse over permissioner og hospitals- eller lazaretophold. Og så til sidst afslutningen med arbejder- og soldaterrådets ${ }^{26}$ stempel; forudsættende flugten og tilbagetoget gennem revolutionen, før hjemmet er vel nået.

Men før det kom så vidt, er det underligt at forestille sig en ung, dansk mand i en kasernegård i Berlin, som rekrut i Kaiser Franz Gardegrenadér Regimentet. - I lange rækker holder de hinanden i hænderne, parat til indøvningen i retmarschen, »the prussian goosestep«, som englænderne har kaldt den. - På: »Frei« begynder alle de lange garderben at svinge, løse $\mathrm{i}$ hofterne, mens alle miner spændes, og så kommer det: "weg “, og støvlerne suser til jorden, og rækkerne avancerer med tordenbrag, blussende af anstrengelse, til Feldwebelens brøl.

Det var nu vore jævnaldrende, men ellers var det jo sådan, at bogstavelig talt hver den man talte med, havde været med. Underligt, når man ser fiskeren ved sin aftenpibe uden for sit hus efter endt dagværk, at vide, at han har været engelsk krigsfange i Kalkutta. Eller en anden, som i revolutionsdagene, med den røde fane på panserautomobilet, jog fra Kiel til Hamborg. I Åbenrå traf jeg en sønderjyde, som rullede cigaretter med en franskmands hele elegance.Han havde været krigsfange og arbejdet i vinmarkerne i Auvergne (Aurillaclejren). ${ }^{27}$ Dér havde han lært kunsten. Befolkningen dernede havde ingen forståelse af sønderjydernes særstilling. For dem var alle i feltgrå: »les Boches «. ${ }^{28}$ De havde haft det hårdt med 12 timers strengt arbejde hver dag. - Inde i hotel »Rondeel“, umiddelbart foran det gamle slot, maner det fra 


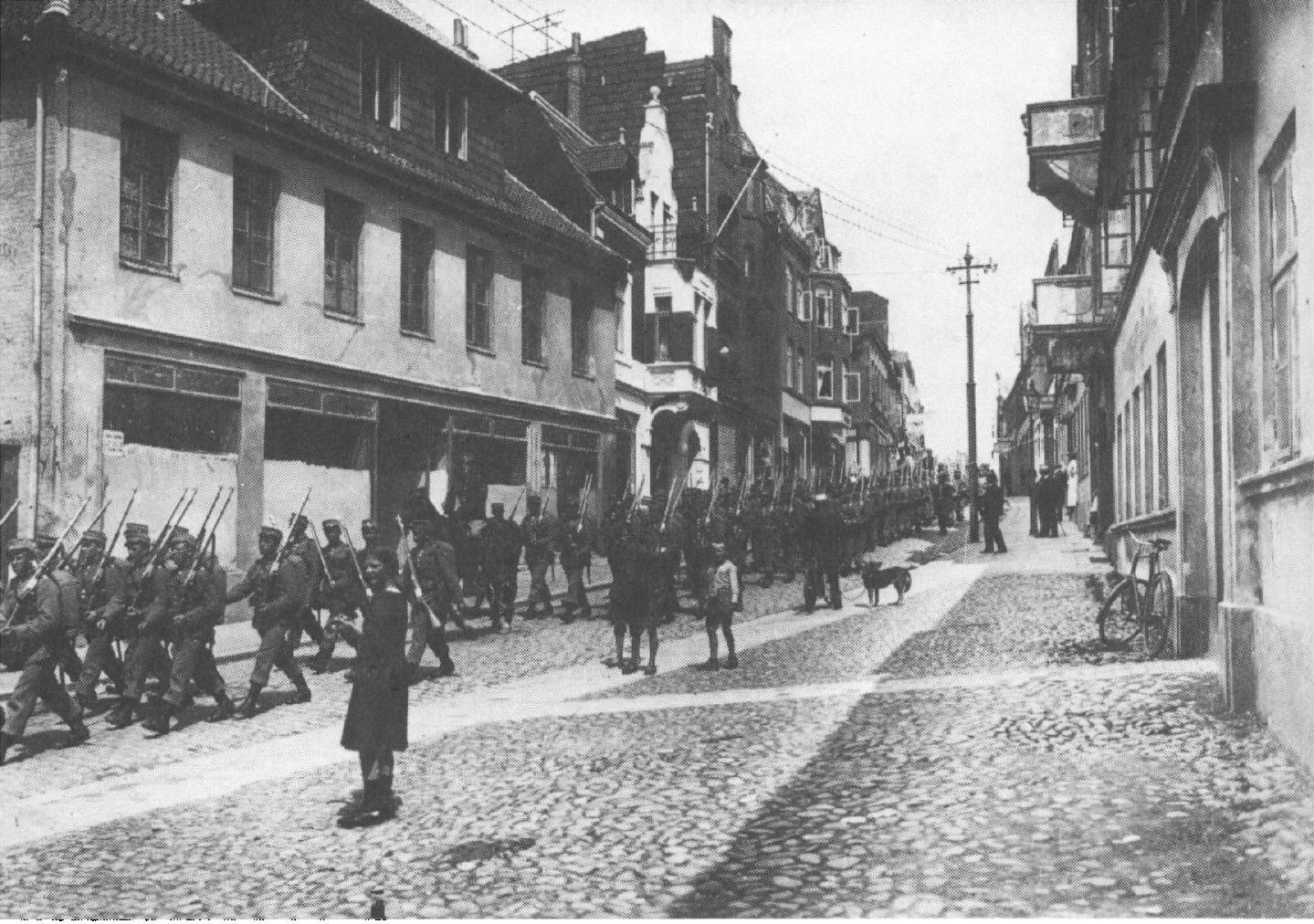

De danske soldater pả march gennem Senderborg by. (Museet pả Senderborg slot).

væggen: »Denen die immer zu kritteln haben, nur drei Tage lang Schützengraben «. ${ }^{29}$ Til gavn for værten, til hvis kogekunst fordringerne bliver slået kraftigt ned, og også for gæsterne, hvis tanker får lov at hæfte sig ved det, som i fem år var ens medmenneskers daglige lod. Jeg talte også med flere tyskere. Deriblandt med én, som havde været fransk krigsfange, først i Bordeaux, men den meste tid på Isle de Rée, og endnu et helt år efter våbenstilstanden. Hadet til franskmændene skælvede $\mathrm{i}$ hans stemme, når han talte, Det der gjorde det aldeles uhyggeligt og håbløst at høre på ham, var, at hans beretninger næsten var identiske med det, som en belgier havde fortalt mig, da han passerede København under krigsfangernes hjemsendelse. Belgieren havde været krigsfange siden november 1914 i Güstrow i Mecklenborg, og også hans stemme skælvede af had - til tyskerne. De to mænd stod dér med samme anklage på hver side af frontlinjen, kun var belgieren langt mere legemlig nedbrudt og oprevet.

Henimod slutningen af mit ophold dernede, var jeg i længere tid beskæftiget med nogle store, dekorative arbejder til genforeningen. Jeg stod i 
en vognport, og fra malerværkstedet ovenpå fik jeg hver dag besøg af svendene, der var tyske, én af dem var fra en by, der hed Hindenburg, og som med levende interesse iagttog arbejdets gang. - Når så der var diskuteret om billederne, "nichts geht über die Lazurtechnik-«, endte det med, at en af dem kom med en eller anden bemærkning om krigen, som straks fængede, og så var vi med det samme i en brandstorm af krigsoplevelser. Den ene fortalte fra sin kant og den anden fra sin, i munden på hinanden og voldsomt gestikulerende. Tilsammen et blændende levende billede af krigslivet på den tyske side, revet ud af al logisk sammenhæng, men med sproget lige ud af skyttegravene, sproget og alle bevægelserne i alle situationer. - Sådan stod man med håndgranaten, sådan slyngede man den, roligt, vis på indstillingstiden, eller sådan - $i$ et febrilsk jag - de første gange. Håndgranaterne synes $i$ det hele taget at have spillet en hovedrolle. En af kammeraterne, der trængte til en afsvalelse, får sendt en hvæsende håndgranat ned for fødderne af sig i det hjørne af skyttegraven, hvor han står, og stirrer stivnet af rædsel, indtil den går ud af sig selv, eksplosionsstoffet var fjernet. Meget optaget var de også af den raffinerede situation, som kan fremkomme, når man har indstillet håndgranaten til eksplosion og lige har beregnet tid til kastet (den skal helst eksplodere lige for den rammer jorden), og den så griber fat f.eks. i en fingerring, idet man vil slynge den fra sig, så kan der komme fart over personen. De fortæller mere til hinanden end til mig, sammenligner den enes oplevelser og erindringer med den andens. Russerne, der var nogle »dumme Kerls", som kyssede fligen af ens kappe, selvom man sparkede til dem. Der var natlige snigpatruljer igennem pigtrådsnet. Saksen har man $\mathrm{i}$ hånden parat til at klippe. En af kammeraterne bliver lidt tilbage, en af håndgranaterne, der hænger ved bæltet, har haget sig fast, det er vanskeligt at komme løs - og så lyder eksplosionen - kaput. - „Die Flammenwerfer “ Erindringen derom synes ikke at tilhøre denne verden. - De stopper også op og ser mod gulvet og mumler: "Nein, nein, das war zu furchtbar. “ $^{30}-$ Men så er der maskingeværerne. Dem er der humør over. Det er i Berlin, Alexanderplatz, "Strasse frei«, og folk løber ind i portene, op i gadedørene, mens det smælder: rak, tak tak tak.

Den gamle landstormsmand fortæller også, men han venter til maskingeværerne er blevet trætte. Han fortæller, en passant, at en løjtnant, som han godt kunne have været far til, engang kaldte ham en kylling, som ikke endnu havde sparket skallerne af sig. De andre kommer så med deres erfaringer i den retning, og meget deciderede kraftudtryk krydses i luften; det syder i dem ved erindringen om kasernegården. Den gamle kommer med en lille historie, som ligesom danner afslutningen på alt det forrige. - Under krigen var der ofte dukket en ungdomserindring op for ham. Det var fra en tyrefægtning i Lima i 
Sydamerika. Tyren havde flået en hest op, men blev kort efter dræbt. Imidlertid var indvoldene blevet stoppet ind i hesten igen ved hjælp af halm, og den nye tyr bliver ført ind. Picadoren sætter sig op på hesten, som de har fået stavlet på benene, men den bryder nu fuldstændig sammen og bliver overladt til sin skæbne. Tyren nærmer sig med sænkede horn, og publikum vejrer. - Den standser lige ved hesten - og giver sig så til at slikke hestens sår. Det havde han aldrig kunnet glemme, og under al den grusomhed, menneskene lagde for dagen overfor hinanden, var dette billede af tyren $i$ Lima's cirkus bestandig dukket frem $i$ hans erindring, mens han havde været derude. -

Allevegne var krigen nået hen. - To storartede, unge sønners ansigter ser fra de store rammer nedover de gamle og søstrene, som er blevet tilbage. Det er i Hundslev midt på Als. Nede ved Kruså peger den gamle vejmand på sin landsby og siger: "Herfra faldt syv i verdenskrigen, min søn var den første, det var ved Namur han faldt; så kom, jo så kom naboens-", og sådan var døden gået fra hus til hus, med kortere eller længere mellemrum, i den lille samling stråtækte huse ved vejen. I 64 havde de fra samme antal huse kun mistet to. - I Åbenrå, mens jeg står og tegner en gammel dør, kommer en ældre mand hen og ser lidt til og tager mig så hen, for at jeg skal se det hus, som hans søn har bygget, hans søn som var en lovende ung arkitekt, og som faldt i Frankrig. - De ensomme gamle. -

Mærkelige sammentræf, der synes rene anakronismer, har krigen gjort selvfølgelige, almindelige.

Man ser et dejligt, gammelt bondehus ved landevejen ude forbi Augustenborg; tømreren, der bebor det sammen med kone, børn og svigerfar, har været med i krigen. Svigerfar er veteran fra 64. "Den gamle« havde spadseret på sine ben til Sønderborg "den daw, nær æ jensere de kom«, og samme ulejlighed gjorde han sig også, da Hans Majestæt kom dertil. Det gamle hus er et helt rustkammer, og med stolthed viser den tykke, gemytlige tømrer mig alle sagerne. En engelsk lyskuglepistol af blankt messing, fisket op ved Yserens bredder, og et dansk forladegevær fra 64 er ligesom samlingens yderpunkter. Desuden et utal af granatsplinter og en tysk, en fransk og en dansk bajonet - til sammenligning. Den sidste er mit eget værge, som det er meget kuriøst at sammenligne med de fremmede. - Mens manden var travlt optaget med at hale alle sine krigserindringer frem, han må være ordentlig belæsset, da han kom hjem, var konen begyndt at tømme chatollet for, hvad det gemte. Hun havde en samling, der var en værdig konkurrent til mandens. Her var, foruden ualmindelig dejlige, gamle bondefajancer, en mængde kobber-, messing- og tinsager, som hun med stor list havde unddraget rekvisitionerne under krigen. Et rigt udstyret kaffestel i rødt og hvidt, hvor 
der på alle stykkerne var malet de sønderjyske piger, var for hende samlingens "pièce de résistance. ${ }^{31}$ Underligt nok stod der kun nedenunder billedet "De sønder ... Piger «. Ordet måtte af en eller anden mærkelig grund ikke skrives helt ud. ${ }^{32}$ Hele stellet var jo en helligdom og var kun blevet brugt til deres bryllup og til hendes mors begravelse. Stort mod havde konen vist under krigen, hvor hun resolut havde styret hele deres bedrift $\mathrm{i}$ de utroligt vanskelige og hårde tider, gået $\mathrm{i}$ marken og passet alle børnene. Hendes største indsats var dog den, at hun havde gjort sin mand, der var født sydtysker, til en god dansker. Allerede i 1908 havde disse to i Odense anskaffet sig et dannebrogsflag, som hun, svøbt om livet, havde indsmuglet $i$ Sønderborg. Hvorfra havde de troen og tilliden? "Credo, qvia absurdum. ${ }^{33}$ - Vi fandt straks det rette forhold overfor hinanden. Hun bød mig mælk af et glas, hvorpå der under to korslagte dannebrogsflag stod: "En skål for gamle Danmark«. Det var Danmark, de gennem mig, den danske soldat, bød velkommen $\mathrm{i}$ deres hus.

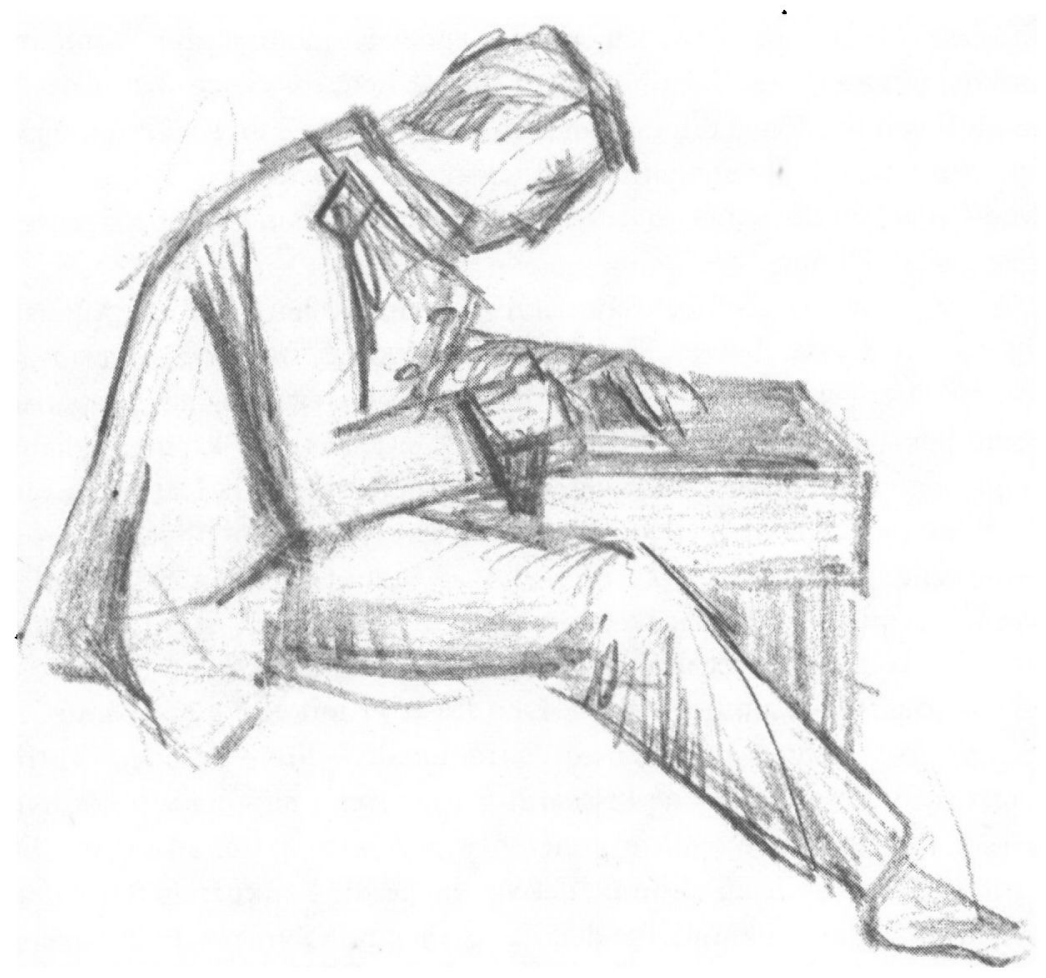

"47 skriver hjem til sin mor. Tegnet af forfatteren pd Marinekasernen i Senderborg den 13. maj 1920. (Privateje). 


\section{Flensborg $^{34}$}

Byen

På hvilken måde man end kommer til Flensborg, med damperen eller ad landevejen, er landskabet af en sådan skønhed, at det bliver i ens hjerte længe efter.

Jeg er kommet til Flensborg med damper, når vandet $i$ den tidlige morgenstund ikke er vågnet og bevager sig uden en lyd, vigende $i$ lange, olieagtige dønninger for skibets stævn, der skærer igennem det. - Den allerførste gang var der en "sangerkrig» om bord. Det var efterslet fra afstemningens ophidselse. - På øverste dæk sad en klynge tyskere og sang i kor en vise med omkvædet: "Wir wollen keine Dänen sein « -, og nedenunder to sønderjyske, voksne spejderdrenge, som lige så stærkt satte i med den under afstemningen meget aktuelle, satiriske omarbejdelse af "Det haver så nyligen regnet. ${ }^{35}$ Duellen blev ved på hele turen, uden at nogen af parterne ville give op, de blev siddende på hvert sit dæk og sang. - Ved indsejlingen til Flensborg spændes ens forventning straks af Mørvigs tårn, der stikker et forundret ansigt op over pynten. Man ser, på den anden side, skibsværftet og mere og mere af byen blive synlig, indtil man tilsidst har den i hele sin festlige, storslåede beliggenhed på alle sider af sig, med de to kæmpemæssige skolebygninger, røde mammutpaladser, tårnende sig op på hver side af dalen, som byen udfylder. ${ }^{36}$ De høje huse oppe på Duborg til højre og Jørgensby til venstre ses lige mod himlen, mens, forneden, hele havnefronten, der går ud og ind med kig op gennem tværgaderne, passerer forbi, idet den gamle havnebygning fra Christian d. 4's tid og et tårnformet, ottekantet hjørnehus er det, der først og fremmest bider sig fast. Over alle tagene i dalen men under bakkekammens husrækker rager Skt. Maries spir i vejret, mens længere tilbage, det meget anseelige Nicolaj spir ses lige mod den klare luft. Ligefor fanges blikket stærkt mellem alle de foranliggende, mindre havnebygninger og højtragende skibsmaster af det berlineragtige hotel Flensburger Hof med de vældige, stift nedhængende fire flag fra gesimsen. Det er et tilfælde, der ligner en tanke, at finde de fire nationers flag i centrum af billedet.

Kommer man ad landevejen er indtrykket et helt andet. Jeg er kommet $i$ bil og i lastautomobil nordfra, og her er det allerførste man ser lige på højre hånd, når man kører ind $\mathrm{i}$ byen, som et mærkeligt og vemodigt bud fra den forsvundne tid. Det er en stor, gammel bygning med en slags rejsestald, og oven over porten står "Louises Minde. 1852. . $^{37}$ Det er to år efter Isted, vi er så stærke som aldrig før, Frederik d. 7. og grevinden residerer på "Lyksborg“, og ballerne i Borgerforeningen er byens brændpunkt. - Men den gamle indskrift er forlængst passeret, og i susende fart går det nu ned gennem 
Nystaden, et skarpt sving, med nød og næppe gennem opgravningernes jorddynger og stenbrokker, og nu lyser for enden af den åbne, lige gade den egentlige indgang til byen, den brede, røde Nørreport med sine trappegavle, roligt modtagende selv en hidsigt rumlende lastautomobil, og så slutter hovedgadens husrækker snævert om os, og larmen fra kæmpekøretøjet lyder med fordoblet styrke, mens undrende blikke følger os gaden igennem, for at finde ud af, hvad det nu er for nogle, som hverken er franskmænd eller englændere, indtil mærket "H.T.K. ${ }^{38}$ bliver kendt, og nysgerrigheden falder til ro.

Se ned ad hovedgaden, eller kom kørende ned ad den i bil eller sporvogn, og alle de vansirende karnapper og opstrittende, umotiverede spir råber højt om, at her har vi en af de ægte, nytyske byer af den sagnagtige hæslighed, som er ved at være klassisk. Set i perspektivisk forkortning er således alt i orden. Men stig ud af bilen eller sporvognen, gå ind på fortovet og tag facaderne i front, man ser så kun de huse, man står ligeoverfor, og mellem karnapperne og hjørnespirene kommer det ene af de gamle patricierhuse frem efter det andet; det er som regn over soltør jord, man lever mere og mere op og kan tilsidst i jubel og glæde gå fra bygning til bygning. - Næste gang man kører gennem hovedgaden er al den hæslige Berliner-gotik tåge, og man ser kun

Forfatterens pas $u d s t e d t$ af Den internationale Kommission. Lidt forstorret. (Museet på Senderborg slot).

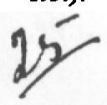

Commission Internationale Slesvig. No. N. Noiregaard

har Mrrachedengeren Ret til, med Befordringsmiddel af

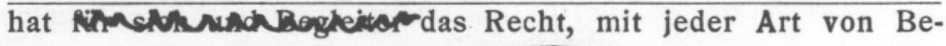
enhver Art, Nen arauktanger fordes i og mellem

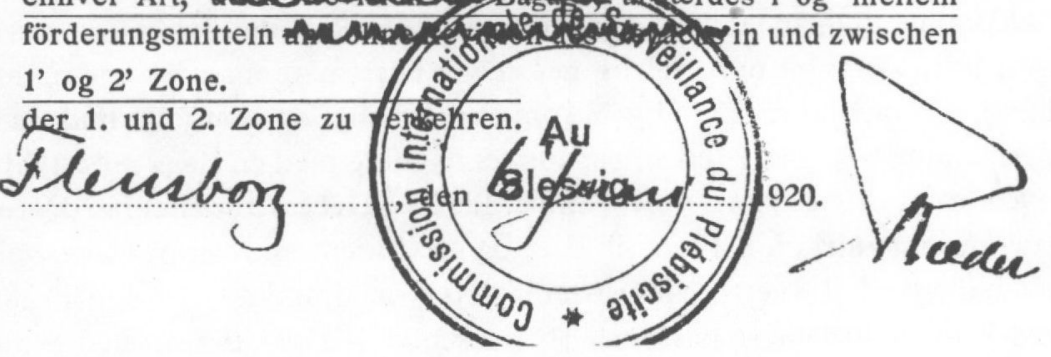




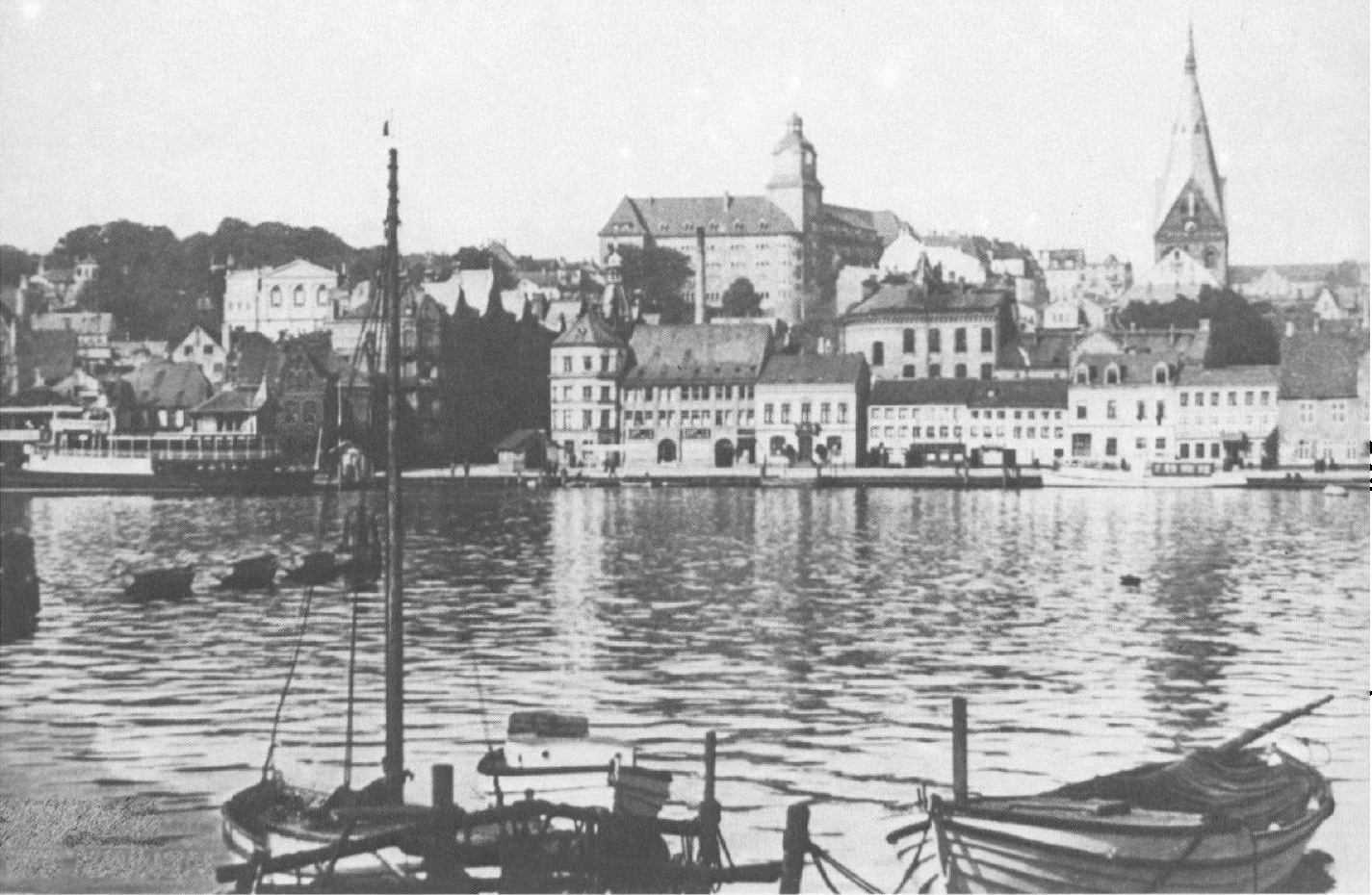

Flensborg set fra havnens ostside i 1920'erne. I midten det ottekantede tårn. herover Altes Gymnasiums store bygning, til højre herfor Mariekirkens spir og yderst til hajre en del af Christian d. 4.'s kompagnihus. (Dansk Centralbibliotek for Sydslesvig).

sine faste kendinge, og ved, når de kommer. - Næst efter Nørreport og havnebygningen, der begge er smykkede med Christian d. 4's navnetræk og "Regna firmat Pietas «, ${ }^{39}$ må jeg nævne det gamle barokapotek med den høje, smalle indgangsdør, hvor, imellem to afbrudte buer, en forgyldt enhjørning med drejet horn kroner Frederik d. S.'s sindrigt sammenslyngede monogram. Bygningen er ganske ubeskadiget og hviler $\mathrm{i}$ de herligste proportioner med sin trefags-front og sit mansard-tag. ${ }^{40}$

Af klassicistiske bygninger har Flensborg en hel del, som fuldt kan måle sig med Københavns, især i nærheden af Søndertorvet. - Kendt fra utallige billeder er den gamle buegang "Schrangen « fra det 16 . århundrede, oppe ved Mariekirken, på hjørnet af hovedgaden og Nørretorv. - En vidunderlig provinsiel, gammel bygning med fladt træloft inde i buegangen få tommer over hovedet på de spadserende. - Herfra kan man gå lige ind på kirkepladsen under de høje træer, d.v.s. først må man passere et iskoldt bronce- og granitmonument med den gamle Wilhelm, "der greise Kaiser ", ${ }^{41}$ ørnen og det hele, før man får lov at hengive sig til den uforstyrrede Flensborg idyl, der følger efter: Mariekirkens brede kor og kapellerne, der skiller sig ud 


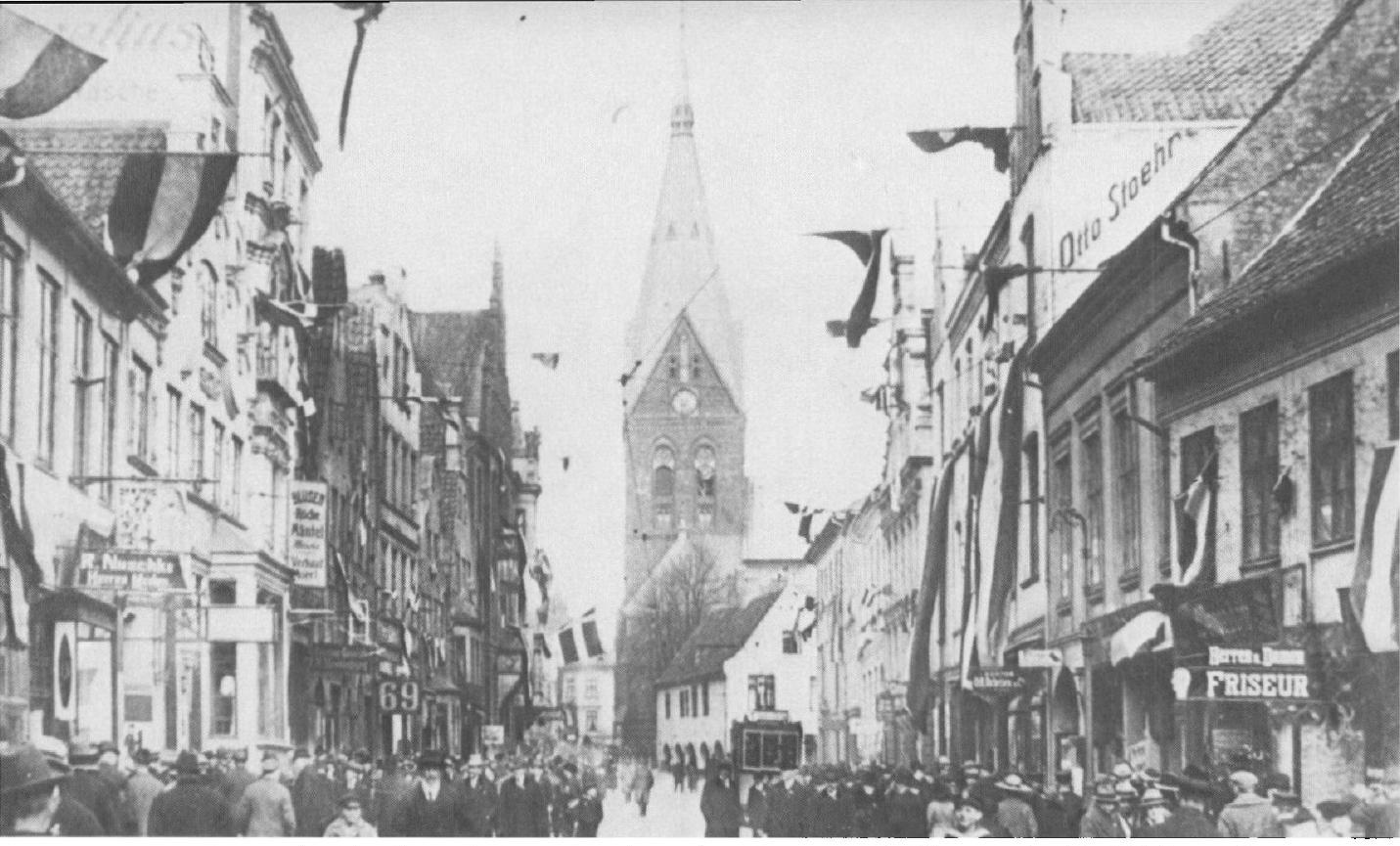

Storegade i Flensborg på afstemningsdagen den 14. marts 1920. I baggrunden Mariekirken og (bag sporvognen) Schrangen. (Dansk Centralbibliotek for Sydslesvig).

derfra; og så ned gennem den morsomme, gamle gang med de høje gavle, de røde, mosgroede tegltage og de grå mure, og som for enden lukkes på en meget bestemt og afgørende måde af havnebygningen, "Kompagnihuset“, der har lagt sig på tværs over passagen, men gennem sin sorte, snævre hvælving lader en stump blå luft og havnens master komme til syne. Man har her $i$ et sluttet billede det gamle Flensborg fra sejlskibenes tid.

Som et bjerg ligger Nicolaj kirkes murstensmasse og vældige tagflade over Søndertorvets aflange, lyse plads. Den fede og svampede "Frau Germania", der står $\mathrm{i}$ bronce foran kirken, gør sig de bemærkelsesværdigste anstrengelser for at spille en rolle $i$ ensemblet, lader sågar en yngling indhugge Jernkanslerens profil ${ }^{42}$ i granitklippen, hvorpå hun sidder, alt forgæves, kirkens om flanderske katedraler mindende vælde lader hendes energiudfoldelse betydningsløs. Men selv alle de takkede murstensgavle på de gamle bygninger, der omkranser torvet, virker kun dæmpet; - underordnet, som det bør sig, kirken. Trods alle moderne, skærende indhug har denne plads endnu et helt middelalderlig-kraftfuldt præg. - Hovedgaden gyder en stadig strøm af vogne, sporvogne og mennesker ned over den lavest liggende del af torvet, mens den højere del er reserveret torvehandelen. Ned ad Friservejen, der oppe fra skrænten i stærkt fald og en stor bue fører ned $i$ torvets højest liggende hjørne, kommer vognene rullende med varer ude fra landet. Forlader man torvet, der fanger al den sol og varme, der kan fanges, og drejer 
ned ad Klostergangen og igennem latinskolen, er man igen lukket inde $\mathrm{i}$ en verden for sig, i snævre, stadigt drejende gyder med ældgamle huse, og hvor man snart taber al fornemmelse af retning og verdenshjørne. Herinde ligger, omgroet af huse, den ældgamle Skt. Hans kirke, og Mølleåen baner sig vej ud og ind, snart synlig, snart høres kun dens brusen.

Men det, der først og fremmest kalder på os danske, er dog den lille, danske kirke i hovedgaden med den høje, grå gavl med det smalle vindue, Frederik d. 4.'s navnetræk og rytterspiret på taget. ${ }^{43}$ Den er mærket, hvorfra man kan finde krigergravene. Fra hovedgaden, ad den lille stejle gyde, der går op langs siden af kirken, når man op til en pragtfuld udsigt med Mariekirkens kobberspir lige for - ak, ikke det gamle! $!^{44}$ - og Ballastbjergets gule grusgrav på den anden side af fjorden. Ganske skyskraberagtigt rejser sig gymnasiet bagved imod solen og kaster en mægtig skygge nedover skrænten. Man

Norretorv og Mariekirken med sit tidligere spir; foran kirken Schrangen og pä torvet Neptunbronden fra 1758. Efter stik af Em. Barentzen i J.P. Trap: Hertugdommet Slesvig, 1864.

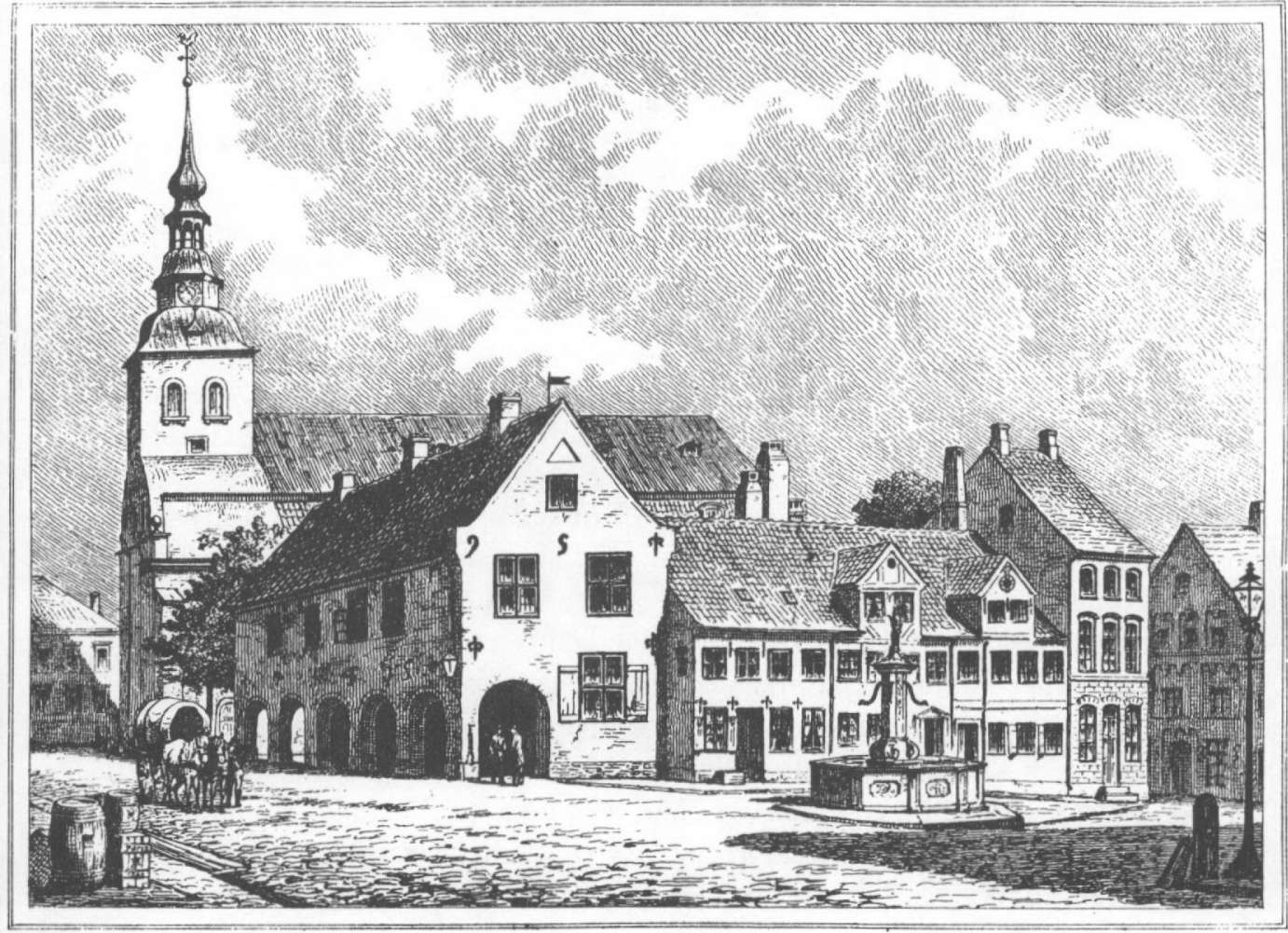

FCIund del. H.ier.sen luth

Pra Barenteen S colithlnet 


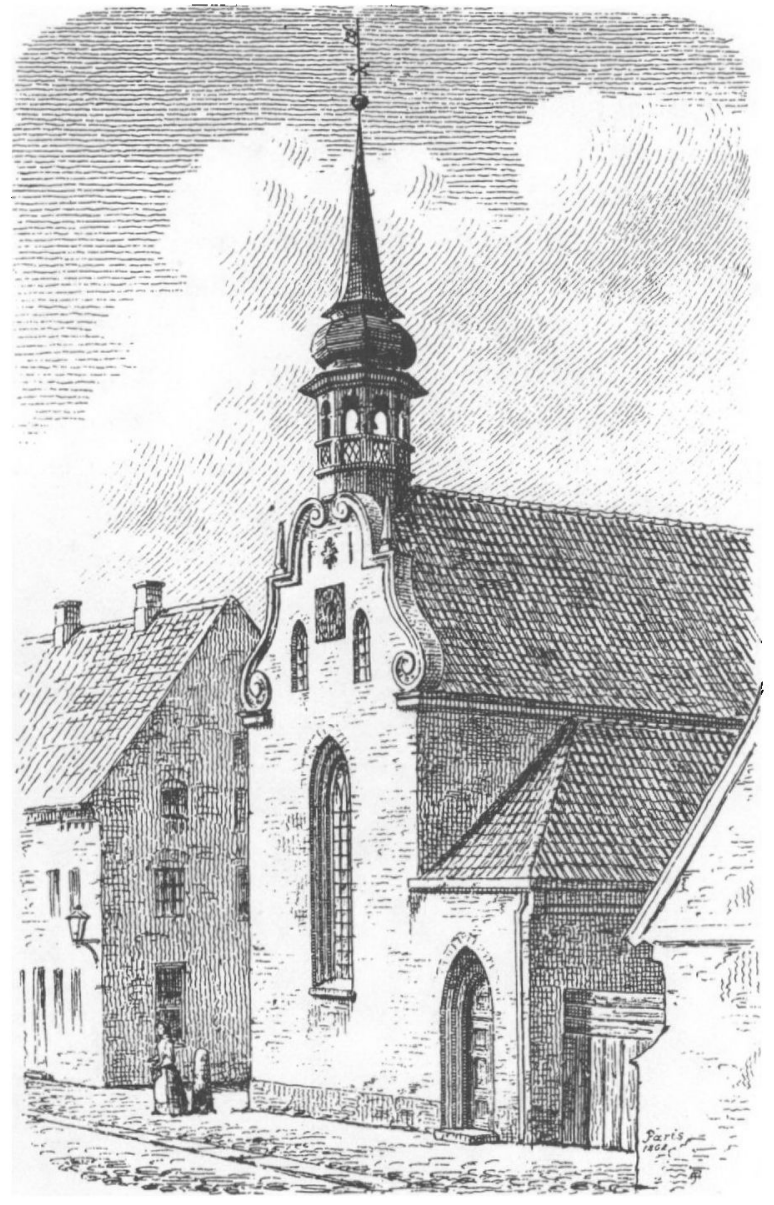

Helligändskirken, den danske kirke i Flensborg; gavlen imod Storegade. Efter J.P. Trap: Hertugdommet Slesvig. 1864.

snegler sig forbi kæmpetårnets fod. - Vrimlen af tage, røgen og støjen, den blinkende fjord, alt forsvinder brat, når man er drejet om hjørnet og er kommet op på bakkekammen bag de store bygninger. - Der er ganske stille og halvlyst i den allé, der fører hen til indgangen til den gamle kirkegård. ${ }^{45}$ Lyset, der kommer ned over det nyklassiske kapels kobberkuppel og gule mure, har først tabt i kraft ved at gå gennem trækronerne. Bygningens rene, strenge arkitektur får således lejlighed til at gøre sig gældende $\mathrm{i}$ et idealt halvlys. Bagved fører snævre, mørke gange med gamle monumenter, hvorimellem der glimter guldregn og syren, og hvorover bøgetræerne løfter deres kroner højt til vejrs i det fulde sollys, hen til den store lysning, hvor den aflange høj med alle de hvide tavler findes. Jeg dvæler ikke længe ved de 
Frau Germania pả Sendertorv $i$ Flensborg, fjernet efter 1920. (Dansk Centralbibliotek for Sydslesvig).

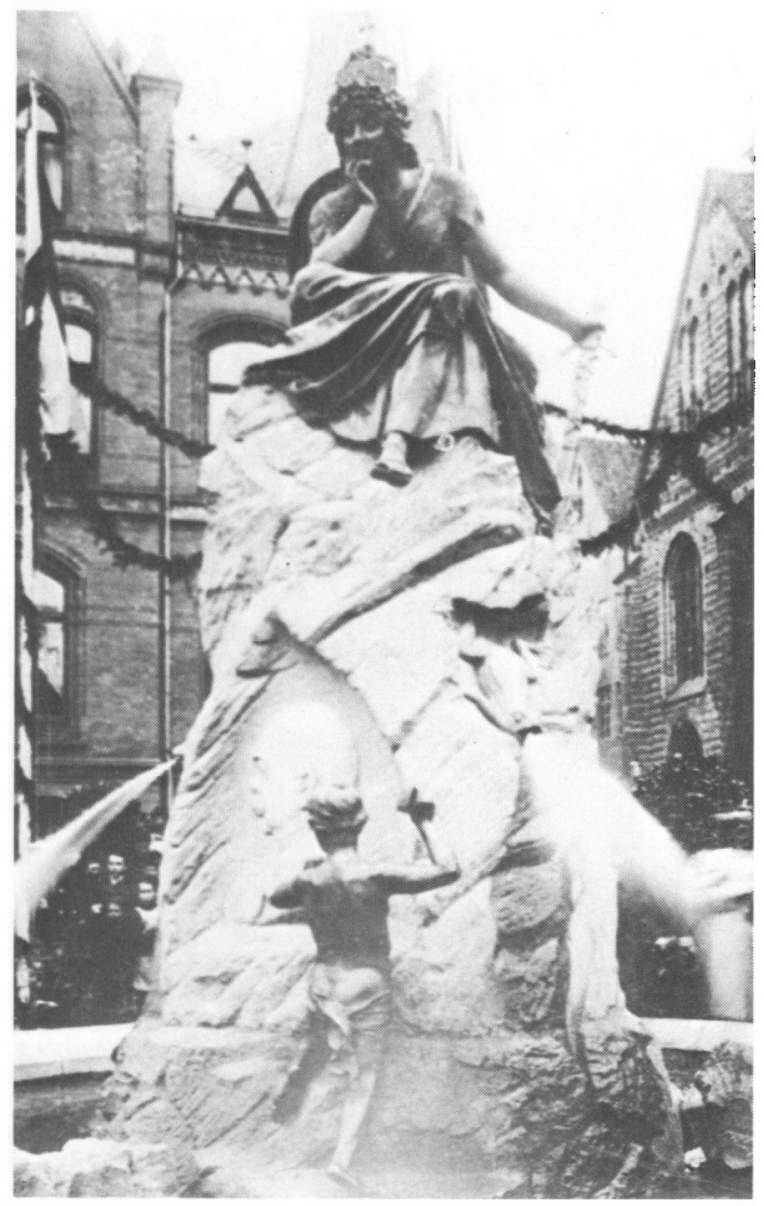

mange, store navne, jeg søger et bestemt. Med de samme faste, klare bogstaver som på kammeraternes stene står det med eet dér - lige foran mig. Så kom den dag altså, da jeg endelig kunne se dette navn hernede, det navn jeg havde hørt om fra min tidligste barndom. ${ }^{46}$

Alt omkring var i den skønneste, første sommerpragt, og herlige violette blomster voksede ovenover stenen og bregner ved dens fod. Hvor billedet må have været fuldendt, dengang løven stod der, den må med sin stolte indskrift have dannet kronen og have givet alle enkeltgravene deres indvielse. ${ }^{46 \mathrm{a}}$

Aldrig noget sted er navne blevet så levende som her. Flere er først døde på lazaretterne i august eller september, men det er Isted, den 25. juli 1850, altsammen. På selve krigergraven er der flere menige, nogle er fra min 


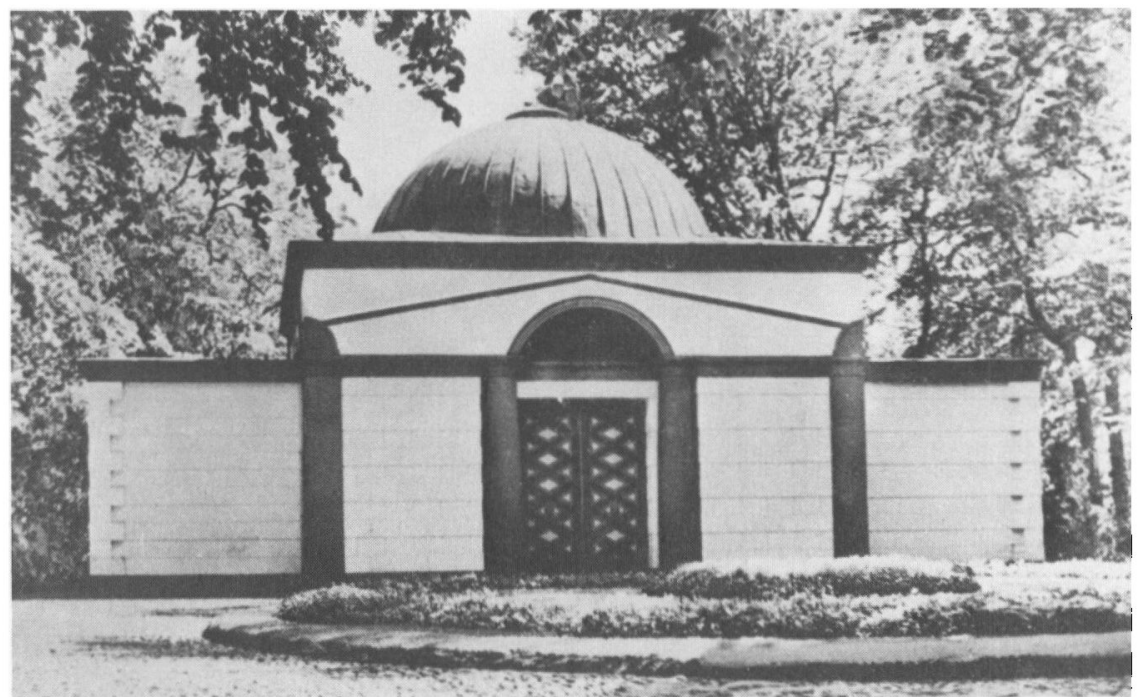

Det nyklassiske kapel med kobberkuppel og gule mure på Flensborg gamle kirkegärd. (Dansk Centralbibliotek for Sydslesvig).

Hejen med krigergravene fra Slaget ved Isted, den 25. juli 1850, på Flensborg gamle kirkegård. (Dansk Centralbibliotek for Sydslesvig).

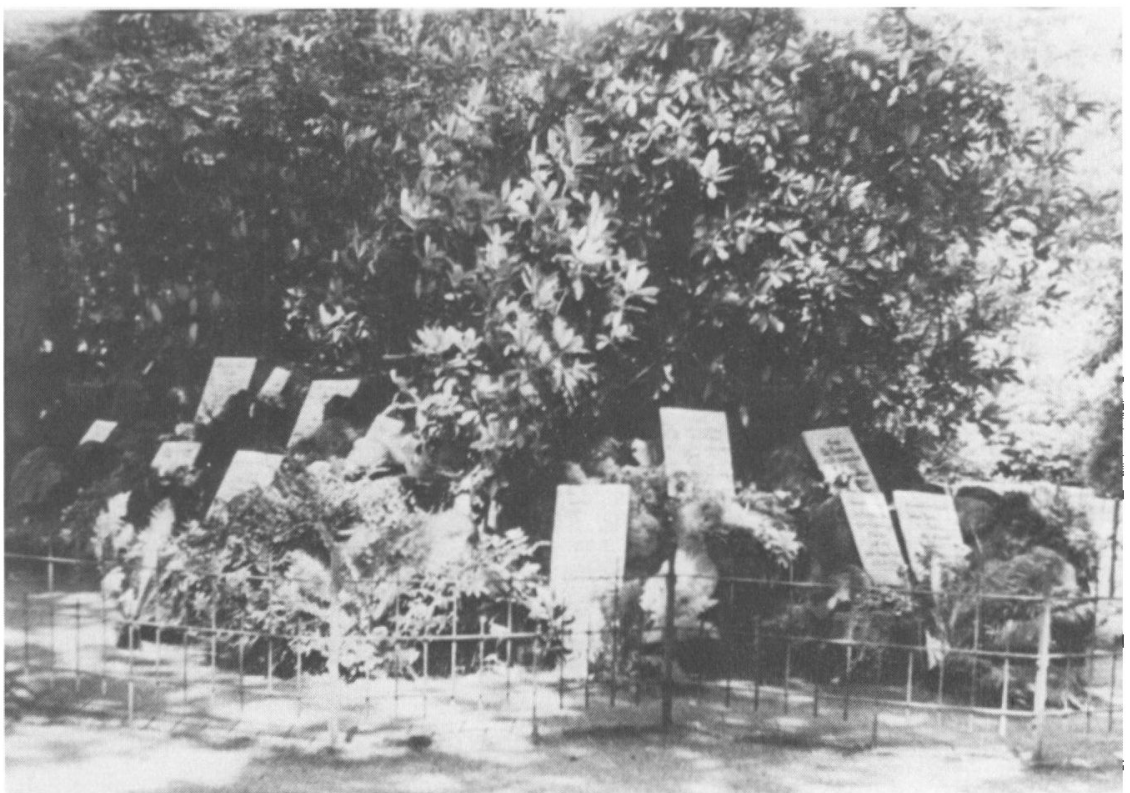


bataillon, 13de, en af dem bærer det mærkelige navn: København; deres stene er nøjagtig mage til de store generalers, der står samlede foran. Ved siden, ud mod hegnet, er der grav ved grav med utallige kors og stene i alle størrelser og materialer, fællesgrave og enkeltgrave, tyske indskrifter og danske indskrifter, store og imponerende monumenter og små og fattige med næsten ulæselige skrifttegn. Det ene indtryk jager det andet, som man går fra indskrift til indskrift, - kun tøvende fjerner man sig.

Ude i Marieskoven er der en plet, som, skønt byen med sine gader når indgangen, endnu bærer et nutidsfjernt præg af fred og ynde. - Det gamle, hvide traktørsted med de "græske" søjler og frontonen med den lille laurbærkrans af jern ses imellem slanke, grålige stammer, og alpejægerne, der sidder her om deres $ø l$, bryder en idyl, hvor krinolinen fra 60 'erne passede ind.

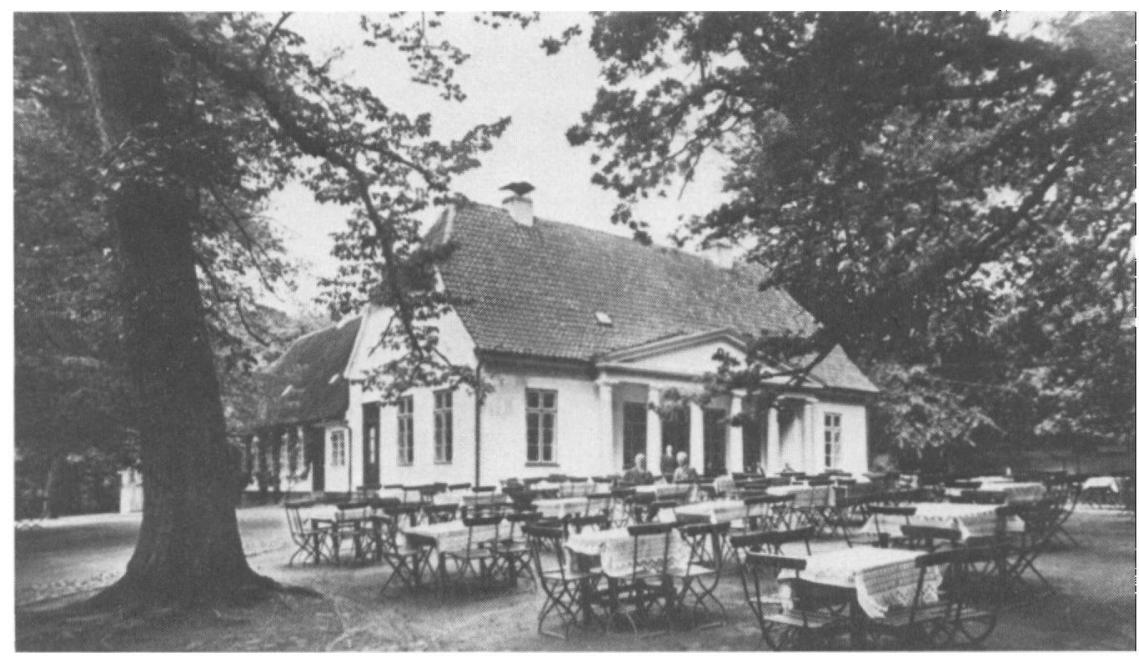

Det lille traktorsted i Marieskoven ved Flensborg. opfort 1825. (Dansk Centralbibliotek for Sydslesvig).

\section{Den internationale Kommission}

For det var jo det: Flensborg var under den Den internationale Kommission. Den var rykket op i en sfære, der gjorde den til noget ganske for sig, og som fik dem, der ikke havde adgang til byen, til at gøre sig de letsindigste forestillinger om alle de vidundere, den gemte, og alle de muligheder, den frembød, hvilket gav sig udslag i, at jeg, hvergang jeg skulle dertil, var overlæsset med de mest aparte kommissioner, som nærmest var et udslag af 


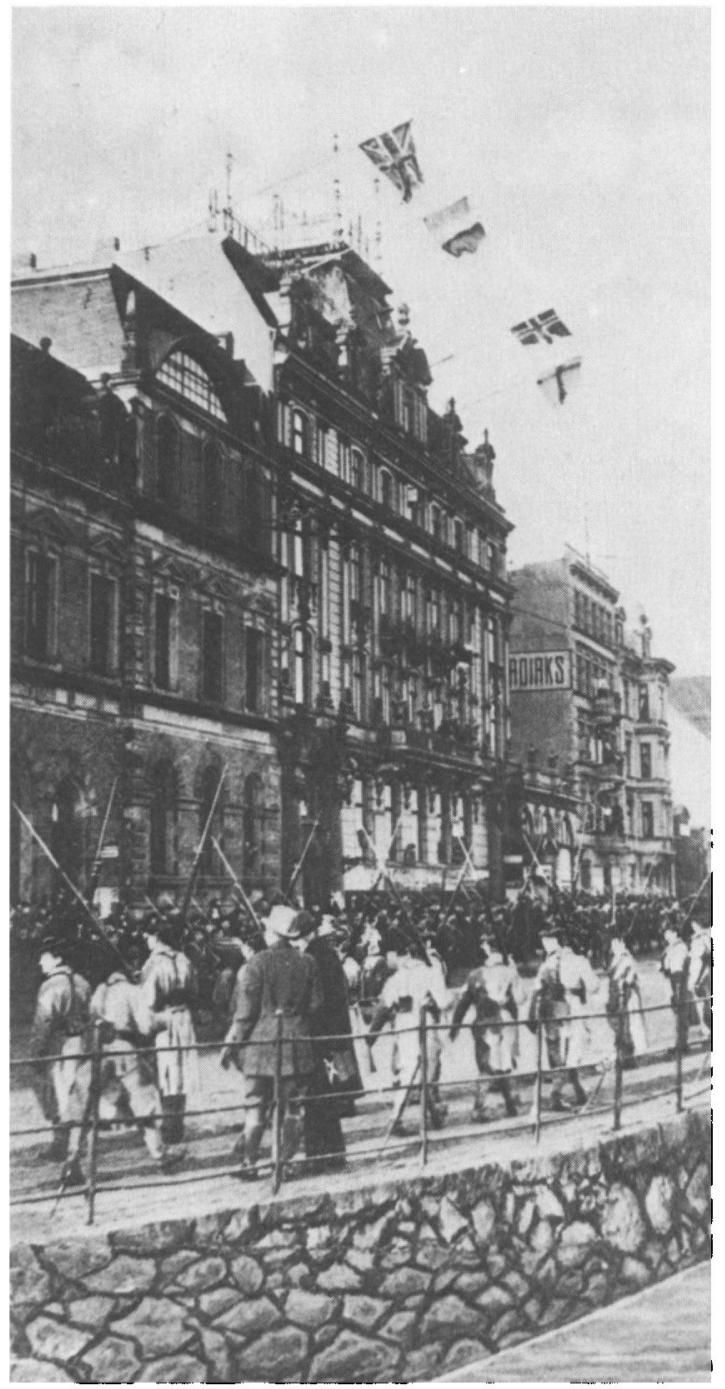

Hotel Flensburger Hof, Den internationale Kommissions hovedkvarter, med de fire flag. det engelske, franske, norske og svenske anbragt på flag. stanger, der ragede ud fra taget. - Der var altid opleb under vagtskiftet foran hotellet. (Dansk Centralbibliotek for Sydslesvig).

den atmosfære af sensation, der efterhånden havde lejret sig om staden. Ganske vist blev også 1. zone styret af samme internationale kommission, men dér havde man den kun for øje i form af alenlange bekendtgørelser og forordninger slået op på alle mure; her var den i højeste grad en faktor i det daglige liv. - Den var centrum, og enhver flagsmykket bil med mærket C.I.S., 
enhver hvidsløret nurse eller aparte klædt gentleman, som man mødte på hovedstrøget, havde Flensburger Hof som basis. - Men Flensburger Hof havde projiceret en kraftig underafdeling ud; det militære hovedkvarter i Mørvig. Det var så heldigt, at mine militære pligter førte mig såvel det ene sted som det andet.

Var man først indenfor $i$ hall'en i Flensburger Hof og kiggede sig om i halvlyset, der herskede under det gule glasloft, hvor de obligate søjler, palmer og læderlænestole hævede det hele op i den kosmopolitiske sfære, hvor alt er ens $\mathrm{i}$ alle fem verdensdele, måtte man vogte sig for ikke at gå på hovedet ind $\mathrm{i}$ en af Kiplings indiske fortællinger og tro sig hensat til officerskasinoet $i$ Amritsar f.eks. - Med nakken lige synlig over lænestolens ryg sad de senede, engelske officerer i samme kulør uniform som det lys, der sivede ned gennem det guleærtefarvede glas, ubevægelige, fåmælte, med "The Graphic« eller "Times« i hånden. På små kurveborde mellem de kolossale, polstrede klubstole var anbragt forfriskninger. Selvfølgelig holdt det indiske eller kiplingske billede sig ikke ret længe. Så passerede civilklædte over hall'en og plumrede det. Men man fik et indtryk af en verden for sig, der, utilgængelig for alle uvedkommende, rørte sig derinde, og man morede sig over den atmosfære af fortrolighed, der herskede mellem dens beboere, som altid havde en eller anden bemærkning parat, når de strøg forbi hinanden. Der var pêle-mêle: nordiske journalister, nurser, franske og engelske officerer og civile kommissionsmedlemmer, opvartere, telefonpiger, C.I.S.-chauffører, portiers og - to civilklædte, danske militære. Herinde under drivhustaget så jeg igen den slags udhalede, lakerede herrer og stærkt pudrede, elegant chausserede damer, som jeg overhovedet ikke havde set en eneste af siden min afrejse for to måneder siden fra København. - Det, der mest satte bevægelse i gestalterne derinde, mens jeg havde stade i en af de polstrede, var, at fru Bruce ("Die Königin " kaldet af tyskerne) skulle have en kurv med æg og lignende sager ud med prof. Mølgaards bil til Kollund. ${ }^{47}$ I kuriøs kontrast hertil foregik vagtafløsningen foran hotellet med al mulig højtidelighed.

Englænderne kom og stillede sig op med ryggen til, franskmændene vis-àvis, så man fra restaurantens brede vinduer så lige ind $\mathrm{i}$ ansigtet på dem. Det var som nat og dag at se den snes mand fra hver sin nation stå dér overfor hinanden. - Englænderne, lange karle, meget røde i ansigtet, hvilket ikke stod særlig godt til den guleærtefarvede khakiuniform, yderst velovervejede $\mathbf{i}$ bevægelserne; og så de små franskmænd i harmonien blåt-brunt (ansigtsfarven) - sort med alle de koldt glimtende sølvmedailler, som de havde hentet sig i København, ${ }^{48}$ på brystet, heftige i bevægelserne, selvbevidste, stærkt præciserende. - Soldaterne prægede $i$ det hele taget gade- og kafélivet næsten som i København i krigsfangetiden, og fremmede måtte undre sig over, at det 
gik fredeligt. - Allerede tidligt søndag formiddag kunne man se alpejægerne i flok drive fra knejpe til knejpe. De yndede også at sætte deres store lastautomobiler, hvori de sad tæt proppede, $i$ rasende fart op og ned ad Angelbovejen til og fra Mørvig, så folk flygtede i vild rædsel for krigschaufførens prøve på sin smarthed.

Der sad endnu en mængde afstemningsplakater rundt om på mure og plankeværker. De allerfleste var afgjort fra dansk side. Omtrent halvdelen af de dansksindede var affattede på tysk. Flere af dem virkede med stor kraft i modsætning til tyskernes, der forekom i påfaldende ringe udvalg med matte idéer, og hvor Uwe Lornsens hoved i en glorie og Holstens nældeblad med de dobbelttydige ord: "Bleibe treu! ${ }^{48 a}$ var de mest fremtrædende. Og alligevel blev resultatet, som det blev.

Jeg fik kun ialt seks gange talt dansk i Flensborg. En af dem, jeg talte med, havde plattysk til dagligt sprog, men var i stand til at tale godt dansk. Således er der sikkert mange, men man må søge nøje for at opdage det. Det er kun de gamle bygninger, der så højlydt og gribende taler et andet sprog end byens.

\section{Mørvig}

Flensborg stræber af al magt efter at nå ud til Mørvig, men endnu er den uendelige Bismarckgade, som fører dertil, byen for lang, og den må give op på halvvejen, så at den sidste strækning af gaden er øde og ubebygget. På vejen derud passerer man den anden af de enorme skolebygninger. Den viser sig at være hul i ryggen som en elverpige og kun facade. Skolebørnene exercerer på legepladsen i delingsvis opstilling med flag og trompeter. Sporvognene er tætfyldte, og beherskes på denne linje af de fremmede soldater. En tommy sidder uendelig nonchalant og umedgørlig på styreapparatet på en sporvogns bagperron til gene for alle, som skal ind og ud. Måske er det ham, der på en væg har skrevet en kæk hilsen til tyskerne fra »one, who has bayonetted eight of them « ${ }^{49}$ Han har $\mathrm{i}$ hvert fald nok nogle på sin samvittighed, som han sidder dér, tæt klemt inde blandt landsmænd til dem, han har dræbt.

Første gang i Mørvig var med lastautomobil. Vi måtte holde stille for at lade en afdeling englændere passere. De overrasker os, som er vant til den atmosfære, der følger med en dansk deling. Hver enkelt mand er ren og velplejet, og uden en stump af det klodsede, sværtede lædertøj, som vi er belemret med. Man kunne se, at de som følge deraf følte sig ganske anderledes frie end vi, når vi marscherer ud, og øjnene så årvågne og roligt iagttagende ud af de glatragede ansigter, på en måde vi ikke er vant til herhjemme fra. 

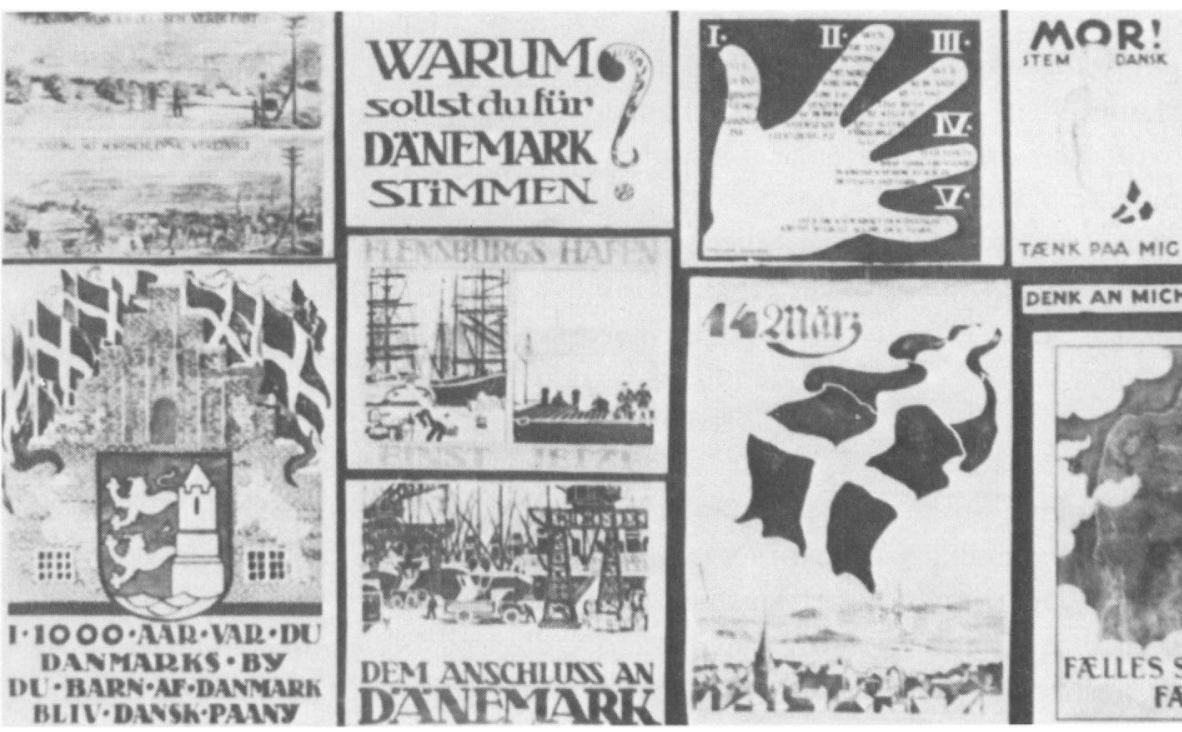

IDenn nieterdie valune if meriss und not DENK AN MICH dicbitmenot

I. $1000 \cdot$ AAR $\cdot$ VAR $\cdot \mathrm{DC}$ DANMARKS - BY DE'BARN'AF'DANMARK
BLIV.DANSK.PAMY

Danske afstemningsplakater, nogle med tysk tekst, opklabet et sted i Flensborg op til afstemningen den 14. marts 1920. (Dansk Centralbibliotek for Sydslesvig).

Delingen kom oppe fra den store centralbygning, det britiske, militære hovedkvarter, som med sine uendelige vinduesrækker og det imponerende trappeanlæg virker massivt og helstøbt ud mod fjorden, men opløser sig indadtil $i$ en række fløje med talrige fremspring og underafdelinger og ligner her med sine haveanlæg, trappegavle og smårudede vinduer mere et kloster end en bygning til militært brug.

Den engelske flåde og alpejægerne havde ikke til huse her, men delte resten af dette kæmpemæssige territorium mellem sig. - Fra Bismarckgaden, ved sporvejens endestation, gik en stejl hulvej ned til det sted, hvor den franske vagtpost stod, men lidt forinden drejede en sidevej brat af til venstre gennem en snæver port mellem to røde murstenspiller og videre ad en svimlende bakke lige ned mod fjorden, for $i$ sidste øjeblik i et nervepirrende, retvinklet knæk at dreje hen parallelt med havnekajen på jæun flade. Dette var en mere end kompliceret tur $\mathrm{i}$ lastautomobil, især da vi ofte havde en ladning, der ragede udenfor til begge sider.

Havnefronten optages af lave, udstrakte magasinbygninger, den engelske flådes oplagsrum og kontorer. Et stykke ovenover disse lavere bygninger rejser sig så den underlige, badehotellignende kasernebygning, som har 
tricoloren vajende fra sit sorte spir, og helt oppe i baggrunden lyser det mægtige, engelske flag fra centralbygningens hovedtårn og underordner sig hele landskabet. - Ude i havnen ligger engelske krigsskibe, grå og sorte, med tøj til tørring i uroligt flagrende guirlander, og længere ude på fjorden et stort hospitalsskib med stærkt lysende røde kors. Af Flensborg ser man kun skibsværftets røde jernskrog, ellers aner man blot byen, som en fremspringende pynt skjuler, ved den tykkere luft oven over stedet. Langt borte på den anden side af fjorden spejler husene $i$ Wassersleben sig i vandet, og røgen stiger op fra kobbermøllen, der ligger skjult i skoven. En skarp fure i trækronerne markerer vejen til Kruså. - Den eneste lyd, der høres, er skridtene af skildvagten, som går op og ned foran magasinerne $i$ "Quick march “, så man straks tror han har umådelig travlt, indtil man et øjeblik efter ser ham komme tilbage om hjørnet i nøjagtigt samme tempo. - Vagtstuen er et enormt lagerrum. Langs væggene står senge, hvori der ligger enkelte sovende. De grønne tornystre står ved fodenden på betongulvet. Der er halvmørkt og køligt til trods for det stærke solskin udenfor. - Midt i lokalet sidder om et bord en 4-5 sultne tommyer. - Hver af de herrer sidder og filer af et stort, nybagt franskbrød, foran dem står en krukke frisk perlende smør og en nylig oplukket dåse med orangemarmelade. Dertil kaffe. - En hurtig vakt appetit fremmaner det sædvanlige morgenmåltid i Sønderborg, det stive, sure rugbrød i tørre, afskårne skiver, det trætørre pålæg, samt margarinen. - Vi indleder en ivrig samtale af gastronomisk karakter, "we get more than we can eat ${ }^{50}$ påstod de, de fik »bacon and eggs« og "pudding (jeg lod som jeg ikke var forbavset) og dertil $4 \mathrm{sh}$. om dagen.

Ovenpå residerede blandt andre "the Paymaster-Commander", Mr. A., hvem alle vore forhandlinger gjaldt. Han boede privat i Mørvig by i en pæn lejlighed, men måtte lide den tort daglig fra sin væg at blive betragtet af en bidsk Hindenburg i bronze. I modsætning til de aktive søofficerer, der talte med hænderne i bukselommen, og gik deres vej, når de ikke syntes, at der var mere at diskutere, var »the Pm.Cm.« udsøgt høflig og klar og tydelig i sit sprog.

Nede i solskinnet sad nogle korporaler og holdt opsyn med mandskabet, der skødesløst hev de fyldte kulsække om bord i skuden, der skulle fragte kul til den danske kommando i Sønderborg. De glædede sig alle til at komme til noget rigtigt efter dette her og snakkede om Ægypten og om Mesopotamien, som vi andre snakker om Fyn og Jylland, men frem for alt havde de mod på at komme til Irland: "Oh, the Sinn-Feiners! ${ }^{51}$ - Resten var et kast med hovedet og et ubehageligt og ildevarslende udtryk $\mathrm{i}$ øjnene. Formodentlig har de $\mathrm{i}$ kun alt for rigelig grad fået deres lyst styret. - Langt om længe lå skibet sejlklart til afgangen næste morgen, som var en søndag; jeg skulle med på farten som 
kontrol på deres eget skib, men vi kom hurtigt på god fod. Det var fader og søn, som hele deres liv havde gået på Elbfart, men nu var søgt nordpå. De talte indbyrdes en temmelig uforståelig dialekt. Sønnen var krigspræget, gusten og sammenbidt og opfarende overfor den sindige gamle, når han var for langsom ved styringen. "Nu, kannst du's besser machen? «, ${ }^{52}$ sagde den gamle. - Det blev ruskvejr og blæste op, og "Adele« skød en mægtig fart, når man betænker dens ikke just slanke bygning, og de 80 tons den havde i lasten. Men den lagde sig helt om på siden og susede gennem vandet, så skumsprøjtet stod som hvide syrener om bovsprydet. Under dette skiftede landskabet hurtigt, kun tårnet blev tilbage af Mørvig, Okseøerne forsvandt, og Glücksborgs vældige, skovbevoksede næs rundede sig udfor os, mens allerede Broager jog sine sylespidse tårne i vejret fra bakkerne foran og straks dominerede hele landskabet, hvordan så fjorden vendte og drejede sig. I løbet af nogle timer var vi fjorden ud og rundede Skelde-næs og Eventyrskoven med alle de grå, søjleagtige stammer, der rejser sig lige i vejret fra klintens brink. - Aftensmaden åd vi fra hver sin ende af den samme pande, kartofler og log af den gamles tilvirkning, og jeg blev opfordret til at tage godt til mig, "sei nicht blöde», ${ }^{53}$ så vi mødtes nok så nydeligt på midten. - Om natten gik vi for anker i Sønderborg havn, og skipperen og jeg sov de retfærdiges søvn under samme ternede dyne i alkoven, der rundede sig efter skibssiden, og med søkortenes lange, hvide ruller over vore hoveder i mørket. - Den gamle holdt til forude ved komfuret, hvor der var varmt. Og næste morgen bugseredes vi ind gennem pontonbroen, hvor mine kammerater stod som vagt $i$ anledning af generalstrejken. ${ }^{54}$

Sidste gang, jeg var i Mørvig (og i Flensborg) var i en meget højtidelig anledning, hvor jeg højofficielt betalte, hvad vi skyldte englænderne for kul og varer. ${ }^{55}$ Der var i Mørvig en febrilsk aktivitet. Alt var i opbrud og bevægelse, alle magasinerne skulle tømmes; det var sidste dag, det britiske flag beherskede Flensborg fjord, "Carysford « lå med dampen oppe, parat til at føre tropperne til København. ${ }^{56}$ - Også »the Paymaster-Commander « syntes grebet af den almindelige nervøsitet; han havde en halv snes affærer, som ikke var afviklede foruden vor, så han lyste op i et smil, da han så mig. Hans ansigt med fuldskægget og de brune øjne bag guld-pincenez'en er for mig uløseligt knyttet til nogle af de ejendommeligste oplevelser i mit liv, og det var virkelig med en slags vemod, at jeg trykkede hans hånd for sidste gang.

En skøn afslutning på alle flensborgdagene dannede så, samme eftermiddag, turen ud til Glücksborg, hvor netop i de dage visse, senere meget omtalte "transaktioner " fandt sted. ${ }^{57}$ Fra mange huse i omegnen vajede de slesvig-holstenske farver; få dage efter tog tyskerne landet $\mathrm{i}$ besiddelse 


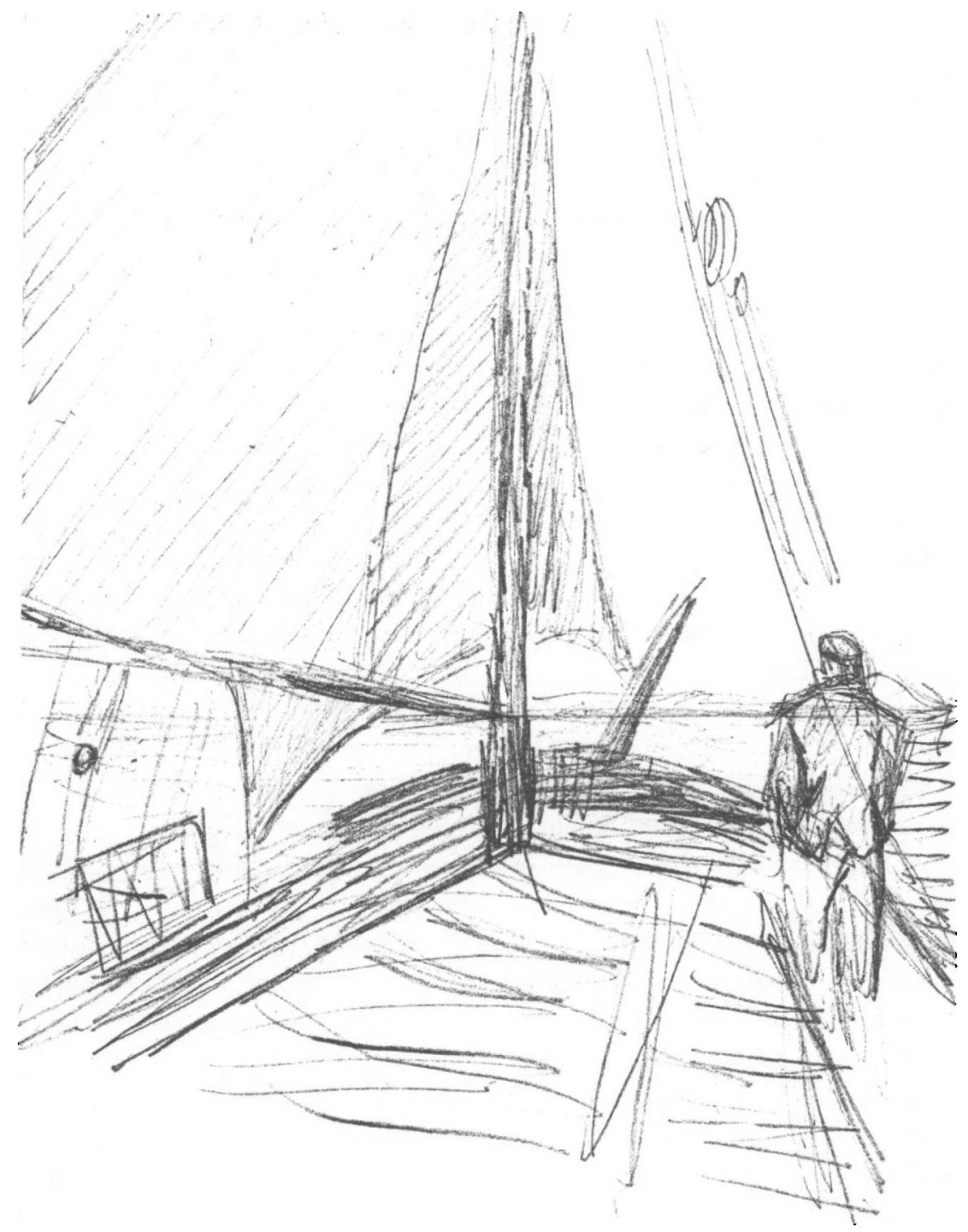

Fra Adeles dak under farten, skitse af forfatteren. (Privateje).

\section{Genforeningen}

Det var omtrent ved denne tid, at man i Sønderborg begyndte at se damer, der var klædt med den bevidste understregning af farver og linjer, som karakteriserer hovedstadsdamen. Tillige markerede de ved alt i deres dragt, at det var sommer, på en bevidst og raffineret måde, så fjernt fra hvad der var 
skik i Sønderborg, at de virkede overordentlig stærkt og fremmed i gadebilledet. Det var de danske embedsmandsfruer, der drog ind. De bragte med sig duften fra hele det bourgeoisi, som nu tilbragte sommeren langs Strandvejen og på Skagen. - Samtidig rejste det ene stillads sig efter det andet foran husene i hovedgaden, og facadevaskerne og malerne arbejdede, så det glinsede på lang afstand, mens i de mindre sidegader og stræder beboerne selv var i gang med hvidtekosten, så det stænkede ud over brostenene. Efter at "Kong Håkon ${ }^{58}{ }^{5}$ havde tømt sin millionlast, var butiksvinduerne med de små, ensomme arrangementer midt $i$ en gabende tomhed blevet propfulde med strålende, nye varer $i$ et udvalg, der ganske tog vejret fra folk. Og en skønne dag gik en mand omkring med en trakkevogn fuld af skinnende røde postkasser, der lå i solskinnet og gassede sig, mens de gamle, hæslige, blå blev skruede af og kørt sammen i en bunke i posthusets gård. Og man så de røde frakker om morgenen gå ud med posten $i$ alle de små gader. ${ }^{59}$ At den dag kom, hvor sønderborgerne kunne lægge brevene i de røde postkasser, havde de selv ofte talt om, men når man tænker på tiden før krigen, begriber man ikke, hvorfra de hentede deres fortrøstningsfulde vished. - Endnu var grænsen lukket, og der var ingen turiststrøm nordfra, men den store strømkæntring var begyndt, kronemønten indført, ${ }^{60}$ administrationen i fuld overgang, og hvert pulsslag førte landet nærmere til Danmark, mens Holsten og Kiel og Rendsborg, før så forbavsende tæt på, blev fortrængt ud $i$ et periferisk halvmørke, og alle ansigter vendte sig mod nord.

Midt i dette store genopbygnings- og genforeningsarbejde var det dobbelt vidunderligt ikke at føre en soldats planløse tilværelse, men at være draget med i det arbejde, der stilede mod genforeningen. Ligefør jeg en morgen skulle til at stige op i lastautomobilet, der skulle føre os til Flensborg, var oberstløjtnanten kommet hen og havde spurgt, om jeg kunne hjælpe festkomiteen med byens udsmykning til festlighederne. $.^{61}-\mathrm{På} \mathrm{hele} \mathrm{vejen}$ derned gennem det pragtfulde sommerlandskab tumlede jeg med planer og idéer, som snart samlede sig om nogle hovedpunkter. - Det havde ved soldaternes indtog virket nedslående og trist at se rådhuset på sin fremtrædende plads ligge dødt og gråt og usmykket. Derfor gjorde jeg det nu til midtpunktet i hele festdekorationen, idet jeg på hver side af det, over Store og Lille Rådhusstræde, rejste en æresport og udfra spirets glugger anbragte otte små flag, som langtvæk kunne ses vinke og blafre i blæsten. Foran facaden flankerede to høje flagstænger rådhusets balkon, hvorfra byens store dannebrogsflag vajede. - Dernæst prøvede jeg $\mathrm{i}$ to store æresporte at få udtrykt noget af det centrale i situationen. - Den ene stod ved indgangen til hovedgaden ved hotel Alssund. Den var meget høj; midt over gaden et maleri af Dybbøl mølle og på hver side af dette de to slutningsstrofer fra verset, der 


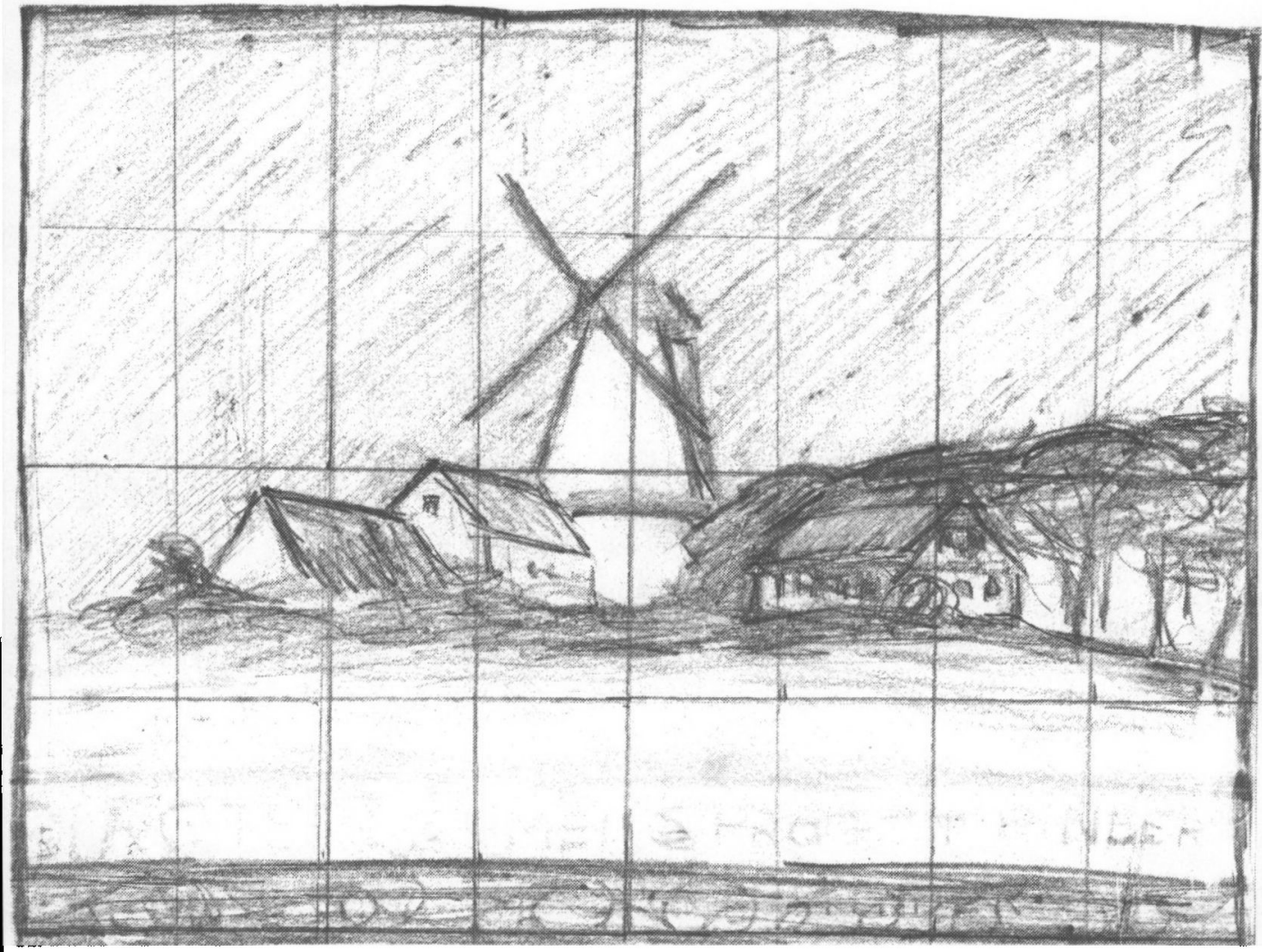

Dybbol Molle. Forfatterens skitse til udsmykning af aresport ved hotel Alssund, juli 1920. (Museet på Sonderborg slot).

er indsat i møllevæggen: "Slægter dø, men sproget binder, fremtid gror af dyre minder ${ }^{62}$ Tværs over jernbanegaden, med front ud imod hovedgaden, rejste jeg den anden æresport, og til hver af pillerne malede jeg her to allegoriske figurer $\mathbf{i}$ overnaturlig størrelse, den ene symboliserende det lænkebundne, den anden det befriede modersmål. Dette foregik i vognporten hos de tyske svende. Ovenover disse figurer, spændende over hele portens bredde, stod verslinjen fra Modersmålet: "Men just som de mente, hun var i bånd og bast $-\varkappa^{63}$ Alle portene blev ganske nøjagtige i proportionerne, som jeg havde tegnet dem; det var meget vigtigt, da materialet, granstammer og grønt, var så simpelt, at det eneste virkemiddel var forholdenes rigtighed, men dette var vanskeligt at få gennemført, da tømrerne var af meget blandet nationalitet og sindelag og talte plattysk, højtysk, frisisk og kartoffeldansk i en pærevælling. Der blev efterhånden flere og flere steder $\mathrm{i}$ byen, hvor man 

kasernen, så pålægget fløj sergenter og menige om ørerne, for der var ikke megen gradsforskel den dag. - Kasernen blev besøgt og beundret fra kælder til kvist, og sceniske talenter blandt det indkaldte mandskab gav Heibergs "Nej“ på et hurtigt opslået friluftsteater ved den grønne skråning i gården. Bagefter spillede orkestret nede foran bygningerne ud mod sundet på den grønne plads, hvor dansen gik som i Dybbøl præstegårdshave, som i Augustenborg og alle de steder, vi havde været, og efterhånden trak flere og flere af de dansende par ud på broen (»Marsbrücke« forhen), og igen var det konstellationen de lysegrå uniformer og de hvide eller lyseblå kjoler, og i en sort, bevæget skare udenom, stod, som vore gaster, vore storartede værter fra de første dage. Vejret var skønnere end nogen sinde tidligere, og med hurra blev tilladelsen til at følge hjem modtaget. De fra de fjernere distrikter blev under megen halløj anbragt $i$ et par store lastautoer og rullede hjem syngende af fuld hals, xldre og yngre lige glade og begejstrede. -

En af de sidste aftener, da hele landet lå som mættet af fest og kun ventede på ordet for at sprænge sidste hæmning bort, cyklede jeg ud til Augustenborg, hvor jeg blev vidne til en scene, som det vil være umuligt at genfortælle uden at berøve den noget af sin sarte ynde. - Det var i den store, næsten tomme sal i Frosts hotel. Der var halvmørkt, skønt det var lyst endnu udenfor. Kun henne ved et vindue stod en lille klynge småpiger; nu og da kom flere til. Da

Udsmykningen af rådhuset og den sydlige del af Perlegade den 11. juli 1920. (Museet pà Sonderborg slot). 


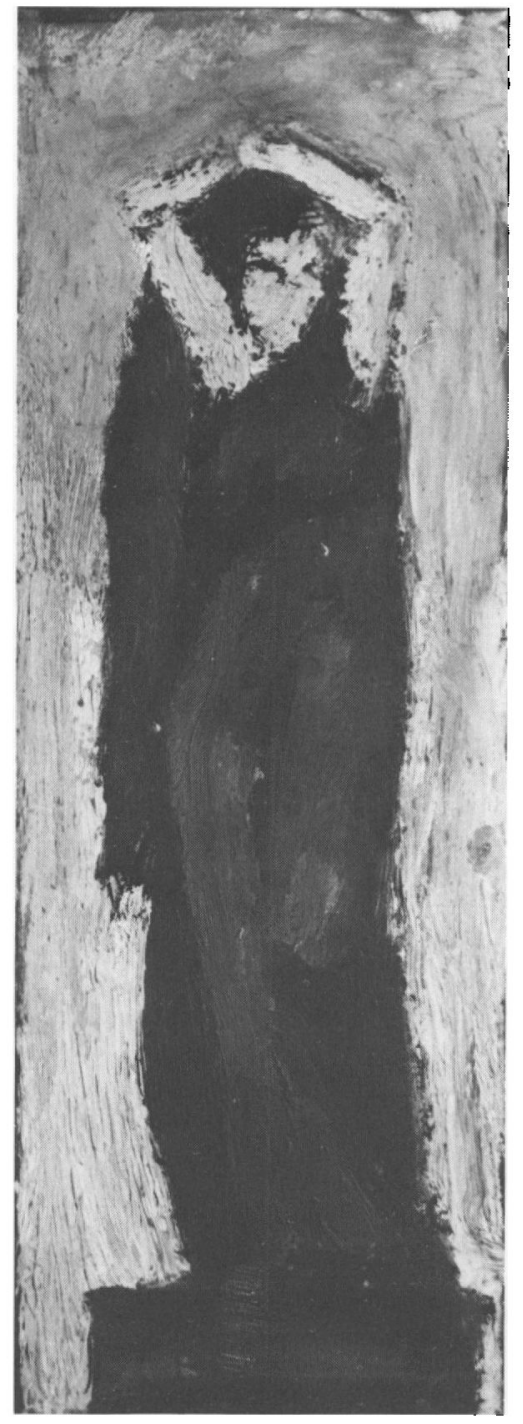

Forfatterens skitse af de to allegoriske kvindeskikkelser til aresporten $i$ Jernbanegade er afbildet pd disse to sider. I venstre side var en sorgende kvinde, der symboliserede det ufri Senderjylland under fremmedherredommet.

de var fuldtallige, gik de op på den lille scene, hvor et voksent menneske omtrent når suffitterne ${ }^{65}$ med hovedet. En purung pige, lærerinde på skolen, tog nu fat. Under hendes ledelse øvede de sig her, aften efter aften, i timevis, på nationaldanse, som skulle danses i Augustenborg på genforeningsdagen. Med englelig tålmodighed blev det samme indprentet dem igen og igen, og med uhyre kejtethed og alvor gik de små til værks, imens de flinkt brugte 
I hajre side stod en kvindeskikkelse, der symboliserede genforeningen med Danmark; $i$ skjoldet de slesvigske lover. (Original i farver på Museet pá Senderborg slot).

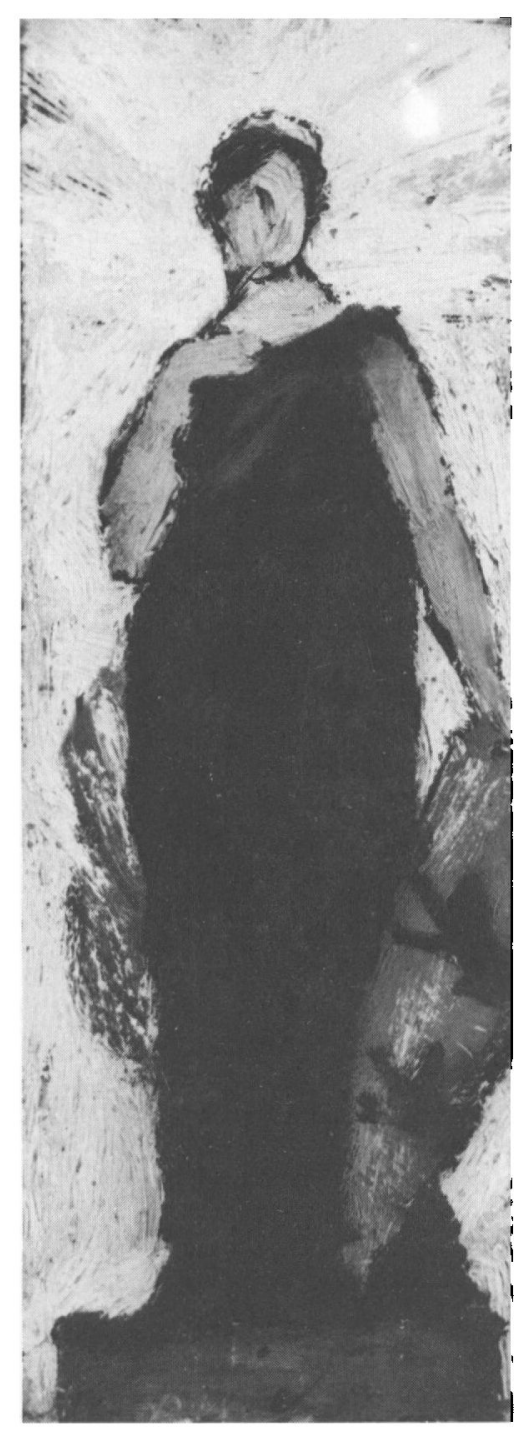

stemmerne, for musikken måtte de selv levere. Sådan gik det med „Hr. Peder kasted runer «, "Nu lider dagen med raske fjed «, "Dybt i havet « og alle Elverhøj-sangene, vers efter vers. Oppe på scenen var det et mylder af kulørte kjoler, der passerede ud og ind, og bare arme strakte i vejret, og ben strakt frem til chassée, altsammen behersket af den unge, blonde pige i den klare, blå kjole mellem alle de små, mørkere bondepiger, og som selv sang højest og 



\section{NOTER}

De med * betegnede noter er udarbejdet af forfatterens nevø lærer Claus Nielsen, Gørslev. Redaktionen skylder Claus Nielsen stor tak herfor, men må tillige bringe en tak til museumspædagog Inge Adriansen, Museet på Sønderborg slot, og bibliotekar Jane Bossen, Dansk Centralbibliotek for Sydslesvig, Flensborg, for hjælp med enkelte noter og med fremskaffelse af billedmateriale.

1. Sønderjysk Kommando ankom til Odense den 16. april 1920. Vi blev indkvarteret hos private, min kammerat $» 47$ " og jeg hos et ganske ungt agtepar $i$ et velhavende hjem, hvor der var to tjenestefolk. Vi sov i billardstuen i to hvidlakerede senge, fik kaffe, kryddere og småkager om morgenen. - Den 18. april fandt faneindvielsen sted $i$ øsende regn. - Odense teater gav i de dage en meget fin opførelse af Maeterlincks "Den blå fugl«, som i høj grad kastede glans over den ørkesløse ventetid. Befalingsmændene anede jo ikke, hvad de skulle stille op med os. Vort civile tøj havde vi deponeret på kasernen, og det var det vi fik brug for, da vi tolv mand $\mathrm{i}$ forvejen sendtes til Sønderborg for at forberede indkvarteringen. I Sønderborg blev jeg og tre andre indkvarteret i fire enkeltværelser på Hotel Alssund, de andre andre steder. Alle var af 1 . besættelsesbataillon, der bestod af mandskab fra $13.0 \mathrm{o} 11$. bataillon. En sergent, et inderligt godt menneske, havde ledelsen. Han boede ovre på Sundevedsiden. Allerede den 2. maj, som var en søndag, tog han tre af os med på en lille tur til Flensborg.

2. *Versailles-traktatens $\S 109$ stk. 1 bestemte, at de to slesvigske afstemningszoner skulle overtages af en fem-mandskommission, "Commission Internationale Plebiscite Slesvig “, dvs. Den internationale afstemningskommission for Slesvig. Tre medlemmer udnævntes af de allierede, to af Norge og Sverige. Kommissionen skulle støttes af allieret militar, udnævne nye embedsmænd, søge råd hos sagkyndige i lige tal fra begge sider og sørge for at afstemningen blev foretaget "... i frihed, oprigtighed og hemmelighed. . Til kommissionen var knyttet et politikorps, der var fordelt over de to afstemningszoner. I efteråret 1919 sammensattes kommissionen sảledes: fra England: Sir Charles Marling (formand), fra Frankrig: Paul Claudel, fra Norge: Th. Heftye, fra Sverige: C.F. von Sydow. Disse fire udgjorde de voterende medlemmer. Generalsekretær for kommissionen blev englænderen Brudenell-Bruce og som særlig sagkyndig tilforordnedes den franske professor Paul Verrier (se note 27). Kommissionen fik hovedkvarter på Hotel "Flensburger Hof “ i Flensborg, hvortil den ankom den 26. jan. 1920.

3. De militære besættelsesstyrker i 1 og 2 . zone bestod af englændere og franskmænd, der ankom $\mathrm{i}$ jan. 1920. En bataillon franske alpejægere blev fordelt mellem Haderslev og Sønderborg, hvortil 30 mand under kommando af løjtnant Demonteville ankom den 22. jan. De fleste var fra Bretagne. Hele den britiske bataillon blev anbragt i Mørvig, den tidligere tyske marinestation ved Flensborg, hvor også et kompagni franske marinesoldater blev indkvarteret.

4. *Bugt på Mainland, Orkney-øerne. Vigtig engelsk flådehavn under begge verdenskrige. Hertil slæbtes den besejrede tyske fláde i 1918. Den 21. juni 1919 sænkede det tyske mandskab skibene.

5. I oversættelse: S.M.S. (Seine Majestäts Schiff - Hans Majestæts skib) „Fuchs«. Sted: BreitGrund. Dato: 29. april 1914. Skydeopgave: Løbende fagtning med ringe afvigelse ved kendt kurs og hastighed. Vejret: klart. Belysning: gunstig etc. - Dagsbefaling nr. 152. Sønderborg 10. juli 1914. Kirkeligt: Søndag den 12. denne mảned kl. 9 formiddag. Katolsk gudstjeneste på Hotel Alssund. Der trædes an på pladsen bag skolebygningen. Afmarsch kl. 8.40 formiddag. Den aldste underofficer har ledelsen etc.

6. "les chasseurs" dvs. "les chasseurs alpins"=de franske alpejægere, "Le Poilu" var den populære franske betegnelse for frontsoldaterne under forste verdenskrig. "La Vie" underforstået: "La Vie Parisienne «, dvs. Pariserliv, fransk vittighedsblad, velkendt også i Danmark. 
7. I oversættelse: "Lille Marie tog næste dag med toget til Neckartal, Neckartal er henrivende, sådan noget har man aldrig set. Åh, du min Neckartal, dér blomstrer syrenerne, når foråret kommer, vender jeg tilbage etc."

8. Telegrammet findes på Museet pả Sønderborg slot, hvortil det blev afleveret af Mogens Kai Nørregaard i 1944.

9. Gæstgiveriet Danmark lå i Sdr. Havnegade og gæstgiveriet Koldinghus i Perlegade 82. Forfatterens lister over, hvor hestene blev opstaldet, findes på Museet på Sønderborg slot.

10. Der var 20 trænheste med vogne og hestepassere foruden ridehestene til staben.

11. *Dederding var en fransk officer knyttet til C.I.S. og formodentlig attacheret Sonderjysk Kommando som forbindelsesofficer. Harald Krenchel, f. 28. maj 1884, stod til rådighed for krigsministeriet for at undersøge indkvarterings- og forplejningsforholdene i Sønderjylland 4. marts-26. maj 1920 og gjorde tjeneste ved Sønderjysk Kommando som kompagnichef 16. april-26. maj 1920. Han var kasernekaptajn i Sønderborg 27. maj 1920-30. juni 1920 og forfatterens chef under alle turene til Flensborg og under forhandlingerne med de engelske myndigheder og C.I.S.

12. Fransk, krigerisk signal til fjenden om at overgive sig.

13. Festen i Dybbøl præstegårdshave fandt sted den 13. maj. Mit brev hjem til mine forældre om denne fest fremkom i Politikken den 20. maj 1920.

14. "Der er tale om Gustav Blom Mackeprang, f. 19. maj 1885, chef for 1. bataillon 4. kompagni ved Sønderjysk Kommando 2. maj-13. juli 1920. Under Danmarks besættelse blev han skudt af tyskerne. - Som det fremgår af skildringen var han en meget afholdt og sympatisk befalingsmand.

15. *I 1878 lod den preussiske stat oprette et "Lærerinde-seminarium" på slottet. Fer genforeningen undervistes alle piger og alle drenge under 14 år på øvelsesskolen i tilknytning hertil.

16. Louise af Mecklenborg-Strehlitz, 1776-1810, gift med Frederik Wilhelm 3., konge af Preussen 1797-1840, moder til den senere kejser Wilhelm 1. Dronning Louise var meget elsket og afholdt og hendes meget tidlige død gav anledning til lyriske hyldest- og sørgedigte af samtidens forfattere. - Auguste Victoria, gift med kejser Wilhelm 2. og datter af hertug Friedrich Christian August af Augustenborg, også kendt som Friedrich der Achte.

17. Med pulverkammeret menes formodentlig "Kammeret“, en høj i slotsparken, hvori der nxppe opbevaredes krudt, men derimod isflager, som bjergedes fra fjorden om vinteren og nedlagdes $i$ højen. - Der er lokalt to forskellige angivelser af hvor $i$ parken hertugens hest skulle vare begravet. - H.C. Andersen besøgte Augustenborg i $1844 \mathrm{og}$ til minde herom var der $\mathrm{i}$ en stor lind nar fjorden indsat en tavle med en tysk indskrift. - De tre edsege iden ydre slotspark, af hvilke de to nu er borte, har fảet deres navn efter et sagn, der fortaller at under disse ege svor hertugen af Augustenborg, hertugen af Pløn og grev Ahlefeldt fra Søgård pá at ville bringe Griffenfeldt til fald (1676).

18. Nu Helgolandsgade.

19. Nis Nissen (1862-1937) var gårdejer i Nordborg og beklædte mange tillidshverv inden for landbrug, kirke og nationale foreninger, bl.a. var han sekretær for Den nordslesvigske Vælgerforening 1896-1910 og fra 1906 tillige kasserer.

20. Henrik Pontoppidans "Det lyder som et eventyr, et sagn fra gamle dage « med melodi af $\mathrm{Th}$. Laub.

21. Det drejer sig om ingeniør Jespersen, som senere blev leder af rutebilstationen i Sønderborg. Han var dengang 27 år og langt mere moden end nogen af os andre.

22. Festen i Ragebøl fandt sted den 21. maj, altså godt en uge efter den i Dybbø̊l præstegårdshave.

23. Populær fransk soldatersang fra første verdenskrig, omdigtet til dansk, jfr. Lili Marlen fra anden verdenskrig.

24. Lybeck er berømt for sine mange skønne kobberspir. Broager kirke har to slanke spir. 
25. "Gammelmark er klintelandskabet øst for Broager ved Vemmingbund. 15. marts 1864 ábnede 26 preussiske kanoner anbragt på Gammelmark ild mod Dybbøl-skanserne, dirigeret af observatører pả Broager kirkes tvillinge-spir, hvorfra man kunne iagttage de danske stillinger og de preussiske granatnedslag. Fra da af blev Dybbøl-stillingen også beskudt fra siden. Skanse 2 lå særlig udsat for ilden fra Gammelmark.

26. Den 4. nov. 1918 gjorde marinesoldaterne i Kiel opror. Arbejderne i byen sluttede sig til oprorsbevægelsen. Der dannedes arbejder- og soldaterråd, og meget hurtigt bredte revolutionen sig ud over hele Tyskland. I Sønderborg oprettedes allerede den 6 . nov. et soldaterråd ledet af marinesoldaten Bruno Topff, og den 10. nov. dannedes et arbejderråd, der forst opløstes den 15. jan. 1920. Rảdets største indsats ydedes $\mathrm{i}$ forbindelse med demobiliseringen af den tyske hær og forsøgene pả at effektivisere ernæringsvasenets administration, jfr. Dorrit Andersen: Rådsbevægelsen i Nordslesvig 1918-20, i Sjy Årb. 1972 s. 147-180.

27. *I Aurillac i departementet Cantal i Auvergne i Frankrig var under ferste verdenskrig en fangelejr for de danske sønderjyder. Professor Verrier (jfr. note 2) gjorde her en stor indsats for de tilfangetagne sønderjyder og søgte med held at vakke forstảelse for deres sarstilling. Han fik gennemført at sønderjyderne anbragtes i særlige lejre, og at de modtog samme gode behandling som fanger fra Alsace-Lorraine. Efter 1. verdenskrigs ophør førte Verrier det første hold sønderjyske fanger til Danmark. Herefter knyttedes han til C.I.S.' arbejde i Sønderjylland.

28. Fransk hånsord for tyskerne.

29. I oversættelse: "De der altid skal kritisere, skulle bare prove tre dage i skyttegravene».

30. Flammenwerfer, dvs. flammekastere, var et barbarisk våben fra 1. verdenskrig.

31. Fransk: glansnummer.

32. Underforstået er sønderjyske. Ordene Sønderjylland og sønderjyske vakte de tyske myndigheders mishag i $1890^{\prime}$ 'erne. Redaktør Janke ved Apenrader Anzeiger kaldte ordet Sønderjylland "en profanation af vort tyske hjemlands navn «, og der blev afsagt dom i 1895 , der forbød brug af ordet Sønderjylland og afledninger heraf. I den anledning skrev redaktør Jes Jessen en af sine berømteste artikler "Et land uden navn «, jfr. Troels Fink; Almanakkens bagside, i Sprogforeningens almanak 1980, s. 33-44.

33. Latin: Jeg tror fordi det er absurd.

34. Min farfar, Johan Peter Nørregaard (1832-1890) var dansk embedsmand i Flensborg fra 1855 til afståelsen i 1864. Min farmor Elna Nørregaard, født Bodenhoff (1833-1919), talte af og til til mig om tiden dernede, og gamle venner fra dengang kom og besøgte hende. Hun var præget for livet af oplevelserne dernede i 1864, da Dannebrog blev strøget, og et andet flag gik til vejrs under fanfarer og hurraråb, og leven væltedes på krigergravene. Derefter havde de kanontordenen fra Dybbøl til den 18. april.

35. *Der er tale om den omarbejdelse af Det haver så nyligen regnet, hvis første vers lyder således:

Senderjyden har underlige vaner

Han er stiv, han er stædig som en hund,

og forgaves den "sittliche" Germaner

sætter lås for hans pæredanske mund.

Lære tysk vil han ej

og han gør »viel Geschrei«

når en tysker vil hjælpe ham på vej.

36. På vestsiden af fjorden ligger Altes Gymnasium, Selckstrasse 1, og på østsiden Oberrealschule, nu Goethe skolen, i Bismarckstrasse.

37. Der er tale om en gammel patricier-ejendom på Åbenråvej i Flensborg.

38. Hærens Tekniske Korps.

39. Latin: Fromhed styrker rigerne, (Danmark-Norge), Christian d. 4.'s valgsprog, der var anbragt på Nørreport fra ca. 1595 og Kompagnihuset på Skibbroen fra 1602-04. 
40. Der er tale om Ratsapotheke, Holm 13, hvis senbarokke facade er fra ca. 1750.

41. Dvs. "den gamle og arværdige kejser «, Wilhelm 1. (1797-1888), preussisk konge 1861-88, udråbt til tysk kejser $\mathrm{i}$ Versailles i 1871.

42. Dvs. Otto v. Bismarck (1815-1898), Tysklands kansler 1871-90.

43. Helligåndskirken blev bygget 1386 som kirke til den allerede da eksisterende Helligåndsstiftelse. Den blev i 1574 indrettet til luthersk kirke med dansk som kirkesprog og fungerer stadig som dansk kirke. Dens facade barer en indskrifttavle med Frederik d. 4's navnetrak og årstallet 1720.

44. Mariekirkens gamle spir fra 1728 blev $1878-80$ erstattet af det nuværende nygotiske tårn.

45. Flensborgs gamle kirkegård er anlagt 1810-13. Her opførtes et kapel i klassicistisk stil med kuppel over en rotunde i bygningens midte. Arkitekt var Axel Bundsen (1768-1832).

46. Navnet på mindetavlen er: Sekondlieutenant af 3. Reservejægerkorps Andreas Carl Herman Rosing Bodenhoff (1813-1850). Han var landmand og min farmors eneste bror. Han nedstammede fra den agent Bodenhoff, der grundlagde skibsværftet på Bodenhoffs Plads på Christianshavn. Hans mor var datter af den store skuespiller Michael Rosing. Han efterlod sig fem uforsørgede børn, hvoraf den aldste var ti år. Han havde meldt sig som frivillig (årstallet 1825 som fødselsår på mindetavlen er fejlagtigt) og havde udmærket sig året forud ved Fredericia. Hans far, min oldefar, sad som forpagter af Bistrup Parcelgård ved Roskilde til 1854.

46a. Billedhuggeren H.V. Bissens Isted-løve, der blev afsløret den 25. juli 1862 og fjernet af preusserne i 1864, havde på soklen denne indskrift: "Trofaste Kæmper i Farens Stund/ modigt har varget vor Odelsgrund/Troskab skal Vagt ved Graven være/Manddom skal skarme Arv og Ere."

47. Fru Bruce, den danskfødte Else Drechsel, gift med den britiske højkommissær for den internationale kommission, mr. Brudenell-Bruce; de boede i Kollund. Professor Holger Chr. Melgaard (1885-1973) var fysiolog og ernæringsforsker. Han var 1919-22 formand for Statens Brødkornskommission og i 1920 ernæringskommissær ved CIS.

48. De franske alpejægere var blevet fejret $i$ København og havde her fảet medaljer til minde om disse festligheder.

48a. Uwe Jens Lornsen (1793-1838) en friser fra Sild, udsendte i 1830 et flyveskrift om forfatningen i Slesvig-Holsten. Heri regnes Senderjylland for et tysk land, der hører sammen med Holsten.

49. Tommy var kælenavn for den engelske soldat, svarer til vores Jens. I oversattelse: en, som har stukket otte af dem (dvs. tyskerne) ned med sin bajonet.

50. I oversættelse: vi får mere end vi kan spise.

51. Sinn-Feiners var den da gangse betegnelse for den irske modstandsbevagelse mod Storbritannien.

52. I oversattelse: Nå, kan du måske gøre det bedre.

53. I oversæettelse: Klem bare på.

54. *Generalstrejken: I løbet af ảret 1920 udbrød en række arbejdskonflikter i Sønderjylland. Arsagen var den i Tyskland galoperende inflation og de deraf folgende prisstigninger, der udhulede lønnen. 7. maj 1920 indtrådte generalstrejke og Sønderjydsk Kommando lod et kompagni soldater under kommando af ovenfor omtalte kaptajn Krenchel (se note 11) sikre livsnødvendige forsyninger ved at besætte banegård, gasvark og elektricitetsværk. I begyndelsen af juni 1920 udbrød atter strejke - en strejke der kom til at omfatte hele Nordslesvig. Lønspørgsmålet var atter àrsag. C.I.S. lod en del personer, der enten var $i$ besiddelse af tysk pas eller hvis papirer af forskellige grunde ikke var i orden, udvise. Også i denne situation greb Sønderjydsk Kommando ind og sikrede gas- og elektricitetsforsyningen og lod ponton-broen mellem Als og Sundeved bevogte for at sikre forbindelsen. Efter nogle dages strejke tilbed arbejdernes forhandlingsudvalg at garantere ro og orden ved broen og de offentlige værker under forudsætning af, at Sønderjydsk Kommando lod sine soldater trække tilbage. Dette skete, men da forhandlingsudvalget ikke kunne hindre fortsat 
uro indsattes påny styrker fra Sønderjydsk Kommando. 12. juni enedes arbejdskonfliktens parter om en overenskomst. Strejkerne var endnu engang bragt til ophør og den resterende del af 1920 forløb uden større uro mellem de konfliktimplicerede parter. Denne militære "indblanding $i$ en arbejdskonflikt var i fuld overensstemmelse med den vejledning chefen for Sønderjydsk Kommando, oberst C.C.F. Moltke, havde givet kommandoet vedrørende den opgave, det skulle løse. Heri står bl.a. "... myndighederne havde de fornødne magtmidler til umiddelbar oprettelse af ro og orden i landsdelen «. Denne vejledning havde udspring i Hans Majestat Kong Chr. d. 10.'s "Kundgørelse for Hæren «-heri hedder det bl. meget andet: "Hver mand skal huske, at kommandoet kommer til Sønderjylland for under nøje samvirke med de civile myndigheder at være alle gode borgeres beskyttere ... «

55. Sidste gang jeg var i Mørvig var den 14. juni. Jeg husker beløbet jeg overrakte; det var en check på $700 £$ sterling. Jeg var dengang helt alene dernede, rejste pr. skib. Mit pas, som jeg havde fået pả Flensburger Hof, gjaldt for færdsel med hvilket som helst befordringsmiddel $\mathrm{i}$ 1. og 2. zone.

56. Carysford forlod Flensborg den 15. juni meget tidligt om morgenen og sejlede til Kobenhavn, hvor de engelske tropper blev fejret.

57. Hvad der hentydes til har ikke kunnet oplyses. Formodentlig kun løse rygter.

58. Kong Haakon var et af DFDS's dengang flotteste skibe, som gik på Norge. Det var i 1920 indsat for at bringe danske varer til Sønderjylland.

59. Antagelig blev de røde postuniformer forst indført den 18. juni og ikke 15 . juni, hvor der ellers indførtes dansk administration på de fleste områder. Det sidste kendte, tyskstemplede brev fra Sønderborg er fra 17. juni og det første kendte, danskstemplede brev er fra 18. juni. Det må formodes, at dansk stempling og danske uniformer indførtes samme dag, dvs. 18. juni (oplysning fra filatelisten, bogholder Max Clausen, Sonderborg).

60. Kronemønten blev indført den 20. maj. Banker og postvæsen brugte hver sin kursberegning, hvad der gav anledning til grænseløse besværligheder. Forvirringen forøgedes ved at marken blev ved at cirkulere, efter at kronen var blevet indført.

61. Sønderjysk Kommando overlod festkomiteen to mand til assistance. Foruden mig ingeniør Jespersen, som havde holdt den uforglemmelige tale i Kathrinelund den 16. maj (ifr. note 21). Vi fik overladt en stor stue på tredje sal i Marinekasernen til tegnestue. Fra København kom firmaet Lysberg og Hansen til assistance. Direktør Hansen, hans assistent, ingeniør Jespersen og jeg drøftede her sammen alle problemerne. Direkter Hansen havde ansvaret for udsmykningen på Dybbøl, og firmaet leverede flag, flagstænger etc. til byens udsmykning; men alt det andet, opstilling osv. måtte den selv ordne, og her trådte vi så til.

62. *Verset er de to sidste linjer i det bekendte digt fra mindetavlen på Dybbøl mølle, forfattet af den islandske prast Thordur Thomasson (1870-1931) og indledt med versene "Tvende gange skudt i grus, atter rejst som møllehus «. Den mindetavle, der i dag kan ses på møllens ydervag, er tavle nr. 2, opsat 1919. Den forste tavle blev opsat af en kreds af danske i 1914, 50-året for 1864, men blev omgående på tysk foranledning taget ned og knust af tyskerne. Den findes på museet i møllehuset.

63. Verset er hentet fra Edv. Lembcke's (1815-1897) sang om modersmålet fra 1859: "Vort modersmål er dejligtw.

64. De fire her næunte er 1) ved Hotel Alssund, 2) og 3) på hver side af rådhuset, 4) over Jernbanegade ud mod Perlegade. Af de fire ovrige stod en ved pontonbroen, en over Perlegade og en ved Ringriderbanen. Den sidste må være den æresport- og tribune, der opstilledes, hvor kongeskibet lagde til.

65. Dekorationselementer, der hænger ned fra sceneloftet.

66. Den 15. juni blev 1. zone overgivet til Danmark, da en note fra de allierede stadfæestede overdragelsen fra dags dato. Den 9. juli underskrev Christian d. 10. traktaten. Herom hedder det i en dagsbefaling til Sønderjysk Kommando, "at når (kirke)klokkerne havde lydt skulle Dannebrog gå til tops, ved kommandoet, medens tropperne paraderede«. 
